\title{
Article
}

\section{The Evolution and Cultural Framing of Food Safety Management Systems - Where from and Where next?}

Wallace, Carol Anne, Manning, Louise and Luning, Pieternel

Available at https://clok.uclan.ac.uk/29266/

Wallace, Carol Anne orcid iconORCID: 0000-0002-1402-2134, Manning, Louise and Luning, Pieternel (2019) The Evolution and Cultural Framing of Food Safety Management Systems - Where from and Where next? Comprehensive Reviews in Food Science and Food Safety .

It is advisable to refer to the publisher's version if you intend to cite from the work. http://dx.doi.org/10.1111/1541-4337.12484

For more information about UCLan's research in this area go to http://www.uclan.ac.uk/researchgroups/ and search for <name of research Group>.

For information about Research generally at UCLan please go to http://www.uclan.ac.uk/research/

All outputs in CLoK are protected by Intellectual Property Rights law, including Copyright law. Copyright, IPR and Moral Rights for the works on this site are retained by the individual authors and/or other copyright owners. Terms and conditions for use of this material are defined in the policies page.

\section{CLoK}

Central Lancashire online Knowledge www.clok.uclan.ac.uk

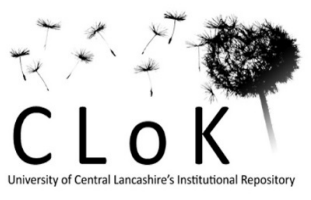




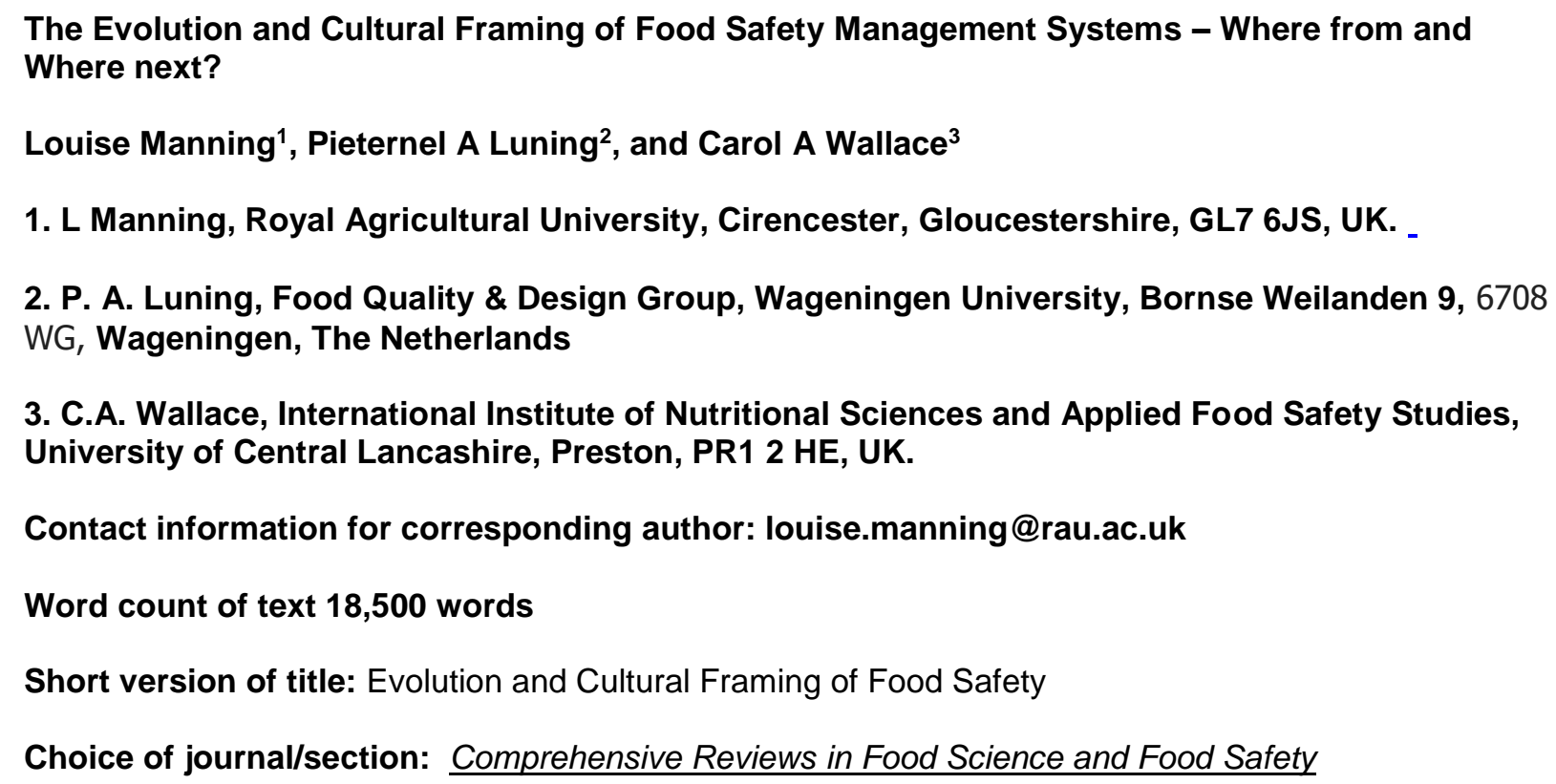




\section{Introduction}

Individuals have the right to expect the food that they eat is safe and suitable for consumption (Codex Alimentarius Commission CAC/RCP, 1969:3). Food safety is the concept that "food will not cause harm to the consumer when it is prepared and/or eaten according to its intended use" (BS EN ISO 22000 2005; Codex, 2003, British Retail Consortium BRC, 2015:112). An organization will develop a formal food safety management system (FSMS) to ensure that food is safe for consumption and also to mitigate foodborne illness, food poisoning or wider considerations of contamination that can cause harm and injury. Therefore, FSMS must be developed, validated and then appropriately applied to ensure their efficacy at all steps in the food supply chain from origin in primary production through to the final consumer. Global distribution of food between multiple supply chain sectors relies upon a consistent understanding by all those concerned as to what food safety is and how it is effectively managed to prevent harm. A universal approach to address food safety hazard identification and assessment, and then FSMS development, validation, implementation, monitoring and verification is the use of the hazard assessment tool Hazard Analysis Critical Control Point (HACCP) based on Codex Alimentarius Principles (Codex, 2009). Indeed, within the European Union (EU) the use of a HACCP-based FSMS is mandatory post-harvest and post slaughter within the food supply chain (EU 852/2004). Moreover, in the last few decades, various consortia of stakeholders have introduced multiple private standards in order to guide/direct the design, implementation, and verification of FSMS. These include the British Retail Consortium (BRC) standard, BS EN ISO22000, Safe Quality Food (SQF), and International Featured Standards (IFS-Food). However, an organizational FSMS is not situated in isolation. People design, implement, monitor and verify the efficacy of a FSMS so their personal interaction with the transactional (technical) elements of both the formal system and other informal practices will impact on the ability of an organization to grow, process, distribute and/or sell safe and wholesome food.

Food safety culture (FS-Culture) is the overarching organizational framework associated with food safety formed by the interplay of actors within the organization (De Boeck, Jacxsens, Bollaerts, \& Vlerick, 2015). FS-Culture develops through the interlinking of three theoretical perspectives: organizational culture, food science and social cognitive science (Jespersen, Griffiths, Maclaurin, Chapman \& Wallace 2016). An 
An understanding how a FSMS is developed and implemented, is also influenced by internal and external pressures and then interacts with the FS-Culture is critical to consistent achievement of food safety requirements. In order to identify the direction and strategy of future empirical research, this narrative review contextualizes the historical development of the theory associated with the development and adoption of FSMS. The review then considers the evolution of a wider academic and industry understanding of the influence of FS-Culture and how such culture frames and enables, or conversely restricts, the efficacy of the FSMS. The systematic approaches to managing food safety using HACCP as a food safety hazard assessment tool and the evolution of private safety and quality assurance standards are critiqued, with particular emphasis on the underlying drive for benchmarking and isomorphism (i.e. reducing differentiation to create increased uniformity in private standard requirements). Further, the food safety challenges in modern food supply systems are explored and the potential requirement for a holistic approach to food safety management and performance is examined. The review is then drawn together to identify potential research gaps worthy of further study and provide direction for application in the food industry.

\section{Evolving definitions and the meaning of food safety}

A food hazard is defined in classic food safety vocabulary as "a biological, chemical, or physical agent in, or condition of, food with the potential to cause an adverse health effect." (CAC, 2003:5; BS EN ISO 22000; 2005; Wallace, Sperber \& Mortimore, 2011:65; Manning, 2017a). The Campden BRI Guide G42 (Gaze, 2009; 2015) expands on this tri-categorization to include food allergens as a fourth category. Mortimore and Wallace $(1994 ; 1998 ; 2013)$ use the CAC (2003) categories, and include allergens within the category of a chemical hazard (Luning \& Marcelis, 2009; Manning, 2017a). Further to the above definitions, BRC (2015:112) has an evolved definition for a hazard as being an agent of any type with the potential to cause harm (usually, biological, chemical, physical or radiological), thus no longer differentiating allergens as a separate category but including the new category of radiological hazards which is gaining wider industry attention. Although Aladjadjiyan (2006) defines radiological agents as physical hazards, there is limited guidance on how this group of hazards should be characterized. The Food and Agriculture Organization's Assuring Food Safety and Quality: Guidelines for Strengthening National Food Control Systems publication (FAO, 2003:3) in their definition of food safety differentiate between chronic and acute food safety hazards stating that: "food safety refers to all those hazards, whether chronic or acute, that may make food injurious 
to the health of the consumer." Further, food safety has also been described as "limiting the presence of those hazards, whether chronic or acute, that may make food injurious to the health of the consumer' (WHO, 2015). Thus, whilst contemporary thinking about food safety still revolves around the control of hazards in food, the concept of acute and chronic illness that is related to those hazards is important. The term "acute" suggests sudden or short term onset (Sprenger, 2014). Chronic hazards are those hazards that have medium to long-term onset, examples being carcinogens, mutagens and teratogenic and immunosuppressive agents (FAO, 1994) or sequelae of acute foodborne illness, e.g. irritable bowel syndrome or Guillain Barre syndrome associated with Campylobacter infection (Ternhag, Törner, Svensson, Ekdahl, \& Giesecke, 2008; Kirkpatrick \& Tribble, 2011). Therefore, depending on the toxic agent of concern, the term food poisoning is considered as being either acute or chronic in terms of onset period and duration of illness (Manning, 2017a). Commonly, the term food poisoning focuses on notions of toxicity specifically i.e. the agent that causes food poisoning being a toxin of either a microbiological origin or other source, whereas foodborne disease or foodborne illness are broader terms relating to infection and/or toxicity. Manning (2017a) suggests that chronic non-communicable diseases (NCDs) such as heart disease, type 2 diabetes, obesity, cancers and illnesses associated with accumulative toxicity could be revisited within organizational hazard assessment. Thus, based on Manning's (2017a) definition, illness, poisoning or intoxication associated with food can be redefined as being:

"a health disorder with symptoms of either of short [acute] or long [chronic] term duration with a specific onset period that is induced by consuming food that is contaminated by biological organisms or agents that have the ability to invade host cells and/or produce toxins once ingested, or food that contains toxic material at the time of consumption, or by consuming an unbalanced diet over a prolonged period of time, leading to over and under nutrition." Moreover, historical and current thinking limits the scope of FSMS to the control and management of the aforementioned food hazards and does not included the wider consideration of prevention of NCDs. Although it can be argued that NCDs may involve 'conditions of food with the potential to cause an adverse health effect'. Indeed, the advent of personalized medicine and personalized healthcare especially around food allergy (Ferrando et al. 2017) means that organizations need to consider how these developments will influence the categorization of food hazards and intoxication in the future (Manning \& Soon, 2017) and the 
124 impact on management approaches to food hazard control and management. The evolution of HACCP125 based FSMS for control of food hazards is now considered. 


\section{Systematic approaches to food safety management using HACCP}

\subsection{Evolution of HACCP-based FSMS}

The adoption of HACCP as a means to develop FSMS evolved from the 1950s and the early days of the United States (US) manned space program (Ross-Nazzal, 2007) (Figure 1). The HACCP approach resulted from a need to identify a preventative assurance approach that could give a high degree of confidence in the food safety program employed rather than a reactive, control-based end-product testing approach. Despite having proved its utility in developing the processes for food production for the US space program nearly sixty years ago, take-up of the HACCP innovation by the food industry was slow. Although the philosophy of analyzing food safety hazards and identifying critical control points (CCPs) came out of this initial National Aeronautics and Space Administration (NASA) work, there was no clearly defined requirement for teams to apply the principles employed. Indeed the term HACCP itself had not been determined initially. Instead, the term was used later by the Pillsbury Company (La Chance, 2006; Wallace, Holyoak, Powell, \& Dykes, 2012). HACCP was not shared publicly in the food industry until 1971 when the Pillsbury Company (part of the NASA space foods program team) presented the initial concept at the Conference on Food Protection (Bauman, 1974; 1990; 1993; Mayes, 1992; Wallace et al. 2012). Further, the technical approach of HACCP has evolved in terms of how to do it; when to do it; what products and processes to cover; what food safety controls to implement at the process level; and lastly which food safety hazards to manage at CCPs, as opposed to those hazards would be more effectively managed through prerequisite programs such as good manufacturing practice (GMP) and good hygienic practice (GHP).

\section{Take in Figure 1}

Early HACCP had three principles equating to principles 1, 2 and 4 of the current seven principles Codex Alimentarius Commission approach (CAC/RCP, 1969; rev. 4, 2003). Initially, the use of HACCP focused on microbiological hazards, although the physical condition of food was considered in the space program as a potential hazard to instrumentation failure (Ross-Nazzal, 2007; Wallace et al. 2011, Wallace, Sperber \& Mortimore, 2018). The Pillsbury Company expanded the use of HACCP more generally throughout the 1970s in their consumer food manufacturing processes. The spread of HACCP more widely within the food industry was promoted initially in the US by Pillsbury's training of Food and Drug 
Administration (FDA) canned foods inspectors in 1972 followed by the publication of the US canned foods regulations in 1973 (Wallace et al. 2011, 2018). International diffusion of the HACCP approach by US bodies was promoted firstly by a focus in the microbiological area through the US National Research Report, An evaluation of the role of microbiological criteria for foods and food ingredients (NRC, 1985). Subsequently, 1988 saw the formation of the US National Advisory Committee on Microbiological Criteria for Foods (NACMCF) (Wallace et al. 2011, 2018), a body which remains important in international HACCP to this day. The similarly named but independent international body, the International Commission on Microbiological Specifications for Foods (ICMSF), which was established in 1962, also took on the HACCP mantle and in 1988, published the first complete book devoted solely to HACCP (ICMSF, 1988; Wallace et al. 2011). A third group, that began working around the same time, was the Codex Alimentarius Commission's Committee on Food Hygiene (CCFH). The CCFH and NACMCF groups both started working on documents to define the HACCP system and provided guidelines on its application, resulting in the first definitive HACCP reports: NACMCF in 1992 and CCFH, generally known as Codex, in 1993 (Wallace et al. 2011 , 2018). There were a number of similarities between the two reports (NACMCF, 1992; Codex, 1993), largely due to overlap between membership of the committees and the US serving as permanent chair of CCFH (Wallace et al. 2011, 2018).

The adoption of the HACCP principles by the food industry as a common approach for managing food safety follows the diffusion of innovation (Dol) theory (Rogers, 2003). Diffusion is 'the process by which an innovation is communicated through certain channels over time among the members of a social system' (Rogers, 2003:11). The Dol theory explains the narrative of innovators, early adopters, majority players and laggards. Existing regulatory bodies and industry food safety communication channels spread the message about HACCP as an innovation in food safety hazard assessment and control, convincing more people, companies and/or organizations to become adopters. A number of factors affect the rate of diffusion of any innovation, including social structures and system norms, the presence and reaction of opinion leaders, and the perceived consequences of the innovation (Rogers, 2003). With regard to the HACCP approach specifically, the perceived consequences of safer food and protection of public health remain the principal reasons for adoption. 
182 the flow of HACCP throughout the world was influenced by opinion leaders; initially Howard Bauman himself

183 and then groups of scientific experts who recognized the theoretical benefits of HACCP and/or were 184 involved in early adopter companies. This 'invisible college of HACCP experts' (Demortain, 2007, p9) acted as change agents (Rogers, 2003), influencing the innovation adoption decisions of others via the national (e.g. US NACMCF) and international (e.g. Joint FAO/WHO Codex Alimentarius) food safety committees and conference platforms (e.g. the five Food Safety and HACCP Forums held between 1997 and 2002 in Noordwijk, the Netherlands). These developments led to the publication and adoption of HACCP Principles and guidelines (NACMCF, 1992, 1997; Codex, 1993, 1997, 2003, 2009). Positive views about HACCP and its preventative advantages led to its adoption by many large food companies around the world. This led to further diffusion of innovation to other and smaller companies, driven by continued communication and the development of mandatory legislative frameworks (e.g. Regulation EC No. 852/2004) and private standards (Kotsanopoulos \& Arvanitoyannis, 2017). In addition, the global reach of HACCP, as the chosen approach for developing a FSMS, was facilitated greatly by the status of Codex as an organization i.e. that it is jointly chaired by the UN FAO and the World Health Organization (WHO). This means that between UN trading partners, who are signatories to the World Trade Organization (WTO), Codex reports have the equivalence of legal frameworks (Wallace et al. 2011, 2018).

From these early beginnings, HACCP was gradually accepted around the world, first in manufacturing but later the approach was extended into catering, retail, food packaging and other applications (Figure 1). Thus the seven Codex HACCP principles have become the cornerstone of the systematic design of FSMS in all sectors. However, whilst perceptions of the benefits of the use of HACCP principles are now universal, how HACCP is applied varies in practice. Initially, development of HACCP based FSMS focused on product specific 'HACCP studies' (Mortimore \& Wallace, 2013). Over time, a more generic approach was used where products considered intrinsically to be highly similar to each other, and as a result deemed to have the same inherent food safety hazards, were grouped e.g. meat or seafood products. This product-led approach to HACCP, whether single products or generic groups of products, was then joined by a process-led HACCP approach whereby the hazard assessment is undertaken based on the specific process or processes that are employed in the manufacturing situation (Mortimore and 
Wallace, 1998). The process-led approach considers food safety hazards associated with the ingredients and the role of the process step itself in delivering food safety. The process-led approach assesses how food safety hazards are managed effectively by process CCPs e.g. cooking, pasteurization, metal detection etc. In complex processing operations, typically most manufacturing situations, individual products are made via a combination of processes, e.g. a prepared meal may consist of components that undergo different initial processes, sometimes in different manufacturing locations, and that are then combined before undergoing further processes. This means that the process-led "modular" approach is applied either to individual processes or alternatively to sets of processes that make up the overall product portfolio of an operation (Mortimore \& Wallace, 1998, 2013).

The challenge of trying to manage large numbers of individual HACCP plans and the associated management records, meant the application of HACCP through the modular process-led approach started to take root in the 1990s (Mortimore \& Wallace, 1994; 1998; 2013; 2015; Wallace, 2006; Williams, 2010). The operational challenge outlined here was also a road-block to the early application of HACCP in catering businesses where early adopters wrestled with developing HACCP plans for every single menu item and found that the system was unmanageable and unsustainable. Multiple authors have considered the barriers to the adoption of HACCP especially for small businesses (Vela \& Fernández, 2003; Baş, Yüksel \& Çavuşoğlu, 2007; Taylor, 2008). These barriers include technical barriers and a lack of pre-requisites and operational plans (Panisello \& Quantick, 2001; Galstyan \& Harutyunyan, 2016); a lack of knowledge and skills (Galstyan \& Harutyunyan, 2016); a lack of motivation (Toropilová \& Bystrický, 2015); concern over the depth of change required to implement HACCP (Herath \& Henson, 2010); associated perceptions of bureaucracy (Taylor \& Taylor, 2004; Lowe \& Taylor, 2013); and concern over the associated costs, investment requirements and financial impact (Panisello \& Quantick, 2001; Nguyen, Wilcock \& Aung, 2004; Herath \& Henson, 2010; Galstyan \& Harutyunyan, 2016). However, a key driver to adopt HACCP is that it is a retailer pre-requisite for market access to the food supply chain (Mortimore \& Wallace, 1994, 1998, 2013; Herath \& Henson, 2010; Lowe, \& Taylor, 2013).

The commonly held belief amongst many organizations that the product-led approach was the only "way to do HACCP", i.e. the requirement for multiple specific HACCP plans for all individual recipes and products, was a barrier that certainly did not help promulgate the system beyond the manufacturing stage 
of the food supply chain. This barrier was gradually overcome by pressure from legislation and the need to demonstrate compliance, market requirements and the development of more simplified 'HACCP-based' approaches. Sector specific hygiene codes or self-checking guides were developed in some countries, often aimed to help businesses meet their responsibilities under regulations such as EU No. 852/2004. For example, Safer Food Better Business (FSA, 2017) was first launched in the UK in 2005, Belgium developed self-checking systems for multiple sectors (Jacxsens et al. 2015), and in the Netherlands sector specific HACCP hygiene codes were developed to support food businesses in designing their FSMS (Luning et al. 2002; Van der Spiegel et al. 2005).

Around the same time that modular HACCP systems started to evolve in manufacturing, a further key development in FSMS design emerged, the concept of formalized prerequisite programs (PRPs). Food businesses had previously understood the need for GHPs or GMPs and most applied these within their operations, albeit with a lack of formality in terms of monitoring and verification. Early HACCP teams had a tendency to identify repetitive general hygiene issues as the cause of potential food safety hazards and this, combined with a lack of understanding of the hazard analysis process itself (Wallace, Holyoak, Powell, \& Dykes, 2014) led to identification of large numbers of CCPs, e.g. 600 CCPs in a dry goods mixing operation (Wallace \& Williams, 2001). Although there were critics in the early days (Wallace \& Williams, 2001), the PRP concept is successful because it reduces the complexity of HACCP systems, and recognizes the difference between process CCPs and PRPs (Escriche, Domenech \& Baert, 2006; Mortimore \& Wallace, 1998, 2011). Several definitions of PRPs have been published such as the basic conditions and activities that are necessary within the organization and throughout the food chain to maintain food safety (ISO, 2018). Process CCPs, situated at a process step such as cooking, metal detection, sieving etc., are specifically designed to reduce a food safety hazard to a safe level. Procedures and protocols under the umbrella of a PRP reduce overall food safety risk e.g. cleaning and disinfection, pest control, effective maintenance programs, etc. Therefore, PRPs address and mitigate the general food hygiene issues in any food operation in a foundational way allowing the HACCP approach to focus on specific process hazards that are significant for food safety (Figure 2).

\section{Take in Figure 2}


Further development of the PRP concept came with the understanding that some general hygiene considerations required an additional, tighter or enhanced level of control, usually to prevent crosscontamination risks that would lead to the ingress of significant hazards, for example allergen control where special measures are required to prevent cross-contact (Manning \& Soon, 2017). These types of food safety issues cannot be managed as process CCPs; however, they require more focus than general PRPs that are global rather than hazard specific in nature (Figure 2). This development led to the introduction of the Operational Prerequisite Program (OPRP) concept within BS EN ISO 22000:2005 (Gaze, 2009, 2015). Use of OPRPs tends to be in those organizations seeking certification to ISO 22000:2005 or similar schemes, but there has been much debate among practitioners as to whether OPRPs are a useful addition to FSMS or whether they lead to an extra level of confusion as to how food safety hazards are managed (Mortimore \& Wallace, 2013). The evolving definitions of OPRPs from being 'a PRP defined by the hazard analysis as essential in order to control the likelihood of introducing food safety hazards to and/or the contamination or proliferation of food safety hazards in the products or in the processing environment' (ISO, 2005) to a 'control measure or combination of control measures applied to prevent or reduce a significant food safety hazard to an acceptable level, and where action criterion and measurement or observation enable effective control of the process and/or product' (ISO, 2018) may not have helped to reduce confusion.

For early adopters and other subsequent organizations, the application of HACCP principles came as a form of retro-fit for existing products and processes, perhaps as a result of the need for compliance with third party supply chain standards or as new legislation made the application of HACCP-based systems mandatory, such as Regulation EU No. 852/2004. Applying HACCP to existing processes and products requires a mindset to assess existing food safety hazards and develop strategies to manage them as well as considering additional and emerging food safety hazards and the controls required to reduce the likelihood of their occurrence. The application of HACCP in terms of managing hazards and food safety risk is now considered.

\subsection{Application of HACCP - managing hazards and risk}

The determination of which hazards in a given situation are significant for food safety and, therefore, need to be controlled at CCPs within the HACCP plan, or by operational PRPs, has historically 
been addressed by the application of HACCP principle 1 (Codex, 2009). However, this area of HACCP has been both poorly understood and poorly applied (Wallace et al. 2014). Often HACCP teams are able to identify potential food safety hazards of interest, but then fail to analyze them effectively in terms of their food safety significance in the context of the specific products produced and the processes employed and/or their potential effect on consumers i.e. the assessment of risk is not adequately situated. This is an area where further guidance was recommended by the Majvik Expert Colloquium on 'HACCP - the way ahead' (Codex, 2014) for consideration in the next Codex review, which is currently at Step 3 of the Codex process (Codex, 2017).

Whilst HACCP is commonly described as a risk management system, it is interesting that the term 'risk' is not used in the application of HACCP principles (Codex, 2009). In fact, 'risk' is not defined within the HACCP principles at all and the word only appears once in the Codex HACCP Annex, in the preamble, which states that 'implementation should be guided by scientific evidence of risks to human health' (Codex, 2009). This omission of the term 'risk' is considered surprising by some food safety practitioners and, whilst many HACCP teams do use the term 'risk assessment' as part of HACCP, it too is not included in the Codex international HACCP standard. This may lead to substantial confusion about the process of risk evaluation regarding the responsibilities of food companies and those of national/regulatory agencies (Mortimore \& Wallace, 2013).

Sperber (2001) states that hazard analysis is a qualitative, local decision-making process conducted by a manufacturing organization's HACCP team taking several weeks or months to complete. In contrast, quantitative risk assessment is a decision-making process in which a numerical degree of risk is calculated for a particular hazard. Usually, large consortia that include regulatory, public health, academic, and industry partners conduct quantitative risk assessment activity typically requiring several months or years for completion (Sperber, 2001). The clear distinction made by Sperber (2001) that hazard analysis is qualitative whereas risk assessment is quantitative is of value. Despite the Codex HACCP Guidelines requiring hazard analysis and the determination of significant hazards rather than risk assessment, problems around understanding of the nuances of terminology have contributed to the confusion about the appropriate application of HACCP principle 1 (Wallace et al. 2014). Monaghan, Augustin, Bassett, Betts, Pourkomailian and Zwietering (2017:726) report that risk assessment is a term 
that can lead to confusion as it is applied to both "a scientific process consisting of formal components and quantification of levels of risk as outlined by the Codex Alimentarius Commission (CAC, 2003) and a more general, qualitative approach based more on expert opinion." In addition, Jacxsens et al. (2016) report that risk assessment is hard to elaborate and to understand, and discuss the need for, and development of, training approaches for (semi-) quantitative probabilistic risk assessment calculations or qualitative risk rankings. Thus, the duality of use of the term risk assessment is a weakness in the evolution of FSMS. Whilst food safety risk is described at the regulatory level as "a function of the probability of an adverse health effect, and the severity of that effect, consequential to a hazard(s) in food" (EC, 1997), risk is not always seen purely in this way (Manning \& Soon, 2013). Therefore, qualitative assessment of food safety risk can be influenced by scientific considerations, situational risk assessment, individual perceptions and the propensity and willingness of the organization to eliminate, mitigate, accept or outsource risk as highlighted in BS EN ISO 31000 (2018) and by Kleboth, Luning and Fogliano (2016).

Current approaches to hazard analysis and the identification of significant hazards involve the consideration of likelihood of occurrence and severity of potential effect for each hazard. Codex HACCP guidelines (2009) require the hazard analysis process to identify 'hazards that are of such a nature that their elimination or reduction to acceptable levels is essential to the production of a safe food'. Further, the guidance for conducting hazard analysis states that 'the likely occurrence of hazards and severity of their adverse health effects' should be included, and that 'qualitative and/or quantitative evaluation' of the presence, survival, multiplication, production or persistence of hazards should be considered. Historically, this has been difficult for organizations, in particular small businesses with limited or no technical resource. More recently, semi-quantitative assessment matrices have been developed that allow for a weighting of both the likelihood of the hazard or the severity of the hazard should it occur (Mortimore \& Wallace, 2013, Manning, 2013, Manning \& Soon, 2013). This can lead to a more priority-focused HACCP approach, but appropriate expertise and experience is still required to apply these matrices effectively (Wallace et al. 2014).

Following hazard analysis, CCPs are identified, either via HACCP team decisions and experience or through use of the Codex HACCP decision tree, a binary questioning process with YES or NO answers resulting in the control of food safety hazards at a given point where deemed critical. The remaining Codex 
HACCP principles describe how to manage, validate and verify CCPs, and the operation and effectiveness of the FSMS. The application of HACCP is just one element of a series of building blocks that underpin a FSMS: namely application of HACCP, safe design, development of appropriate PRPs, and adoption of essential management practices (Wallace et al. 2011) see Figure 3.

\section{Take in Figure 3}

The essential management practices that are elements of GMP and good agricultural practice (GAP) include: senior management commitment to food safety in terms of overall mission right through all layers of management within the organization; clear definition of roles and responsibilities with regards to managing food safety; and appropriate training and education. Further, the consideration of the resources required to develop and effectively implement the food safety program; the development of a documented and formalized FSMS with associated process records; and a drive for continuous improvement in meeting pre-defined food safety management goals and objectives are essential practices to adopt. Suppliercustomer protocols require a clear definition of the inputs and outputs for given processes within the internal food manufacturing system and at interfaces between one organization and another. The clear communication of food safety criteria at these interfaces e.g. between supplier and manufacturer and manufacturer to distribution system is essential to ensure consistently safe food product and safe working practices (Manning, Baines \& Chadd, 2006).

Despite decades of encouragement and mandatory requirements to adopt HACCP approaches to develop FSMS, the global food sector still experiences major acute and chronic food safety incidents. Examples of product recalls in 2017 alone include for the US Food and Drug Administration (FDA) ninety five recalls, market withdrawals or food safety alerts for Listeria monocytogenes, twenty three for Salmonella spp. and, an emerging health hazard in 2017, eleven recalls for undeclared sildenafil (Viagra) in dietary supplements (FDA, 2017a). In the EU, an emerging food safety hazard too was fipronil, a toxigenic chemical. Globally, the 2017 European fipronil incident with direct and composite products affected 56 countries and led to 117 notifications on the Rapid Alert System for Food and Feed database (RASFF, 2017). In 2018, the "needles in strawberries" incident in Australia brought concerns over deliberate 
contamination of food (Manning, 2019). So does the HACCP hazard analysis approach deliver especially when considering emerging food safety hazards?

\subsection{Challenges associated with the HACCP approach.}

Has HACCP as a management tool been oversold as a total solution; a silver bullet? Should regulatory bodies and food manufacturers recognize that undertaking hazard analysis and developing an associated FSMS does not deliver zero food safety risk in food supply chains? Should there be more focus on FS-Culture, and its impact on how the FSMS is implemented and verified? These are all questions that arise when considering the challenges associated with implementing the HACCP approach.

Food safety incidents have been associated with multiple weaknesses and factors of influence. These include lack of knowledge, training and expertise (Wallace et al. 2005; Mensah \& Julien, 2011; Wallace et al. 2012, 2014); a lack of awareness and commitment and failures in management or leadership (e.g. Peanut Corporation of America see Manning, Wallace \& Soon, 2016; Manning 2017b); a breakdown in the implementation of a PRP or process design or a lack of resources (see case study of Maple Leaf Foods in Manning, 2017b), weak verification (Powell, Jacob \& Chapman, 2011); or weak maintenance of the FSMS (see case study of XL Foods Inc. in Manning, 2017b). Many of these factors reflect a failure in organizational culture and conditions of control i.e. there is a cultural framing of a food safety program and FSMS that requires consideration.

In addition, it is important to recognize that HACCP is a tool for assessment and management of food safety hazards and is implemented effectively only if both the hazards and the means for their control are clearly identified, understood and communicated within the organization. Emerging types of food safety hazard, if unknown by those in the HACCP team tasked with developing, reviewing or re-validating a HACCP Plan and associated food safety program, will simply go under the radar until there is an incident associated with that hazard. Whilst pathogens may be recognized as potential food safety hazards, emerging chemical hazards such as fipronil, sildenafil, or pieces of golf ball in frozen hash browns (FDA, 2017a) may not. Further, the HACCP approach is often difficult to apply at farm level and there is a growing trend instead to develop risk-based preventive control processes (Monaghan et al. 2017). 
food safety hazard is and what it is not especially in wider considerations of food safety, food quality, food fraud, and food defense. Spink and Moyer (2011) in seeking to characterize food fraud and food safety, and by inference the food safety hazards that need to be considered within hazard analysis as part of a HACCP approach, state that food safety addresses only the unintentional actions that make food injurious to health, whilst food fraud concerns intentional actions of adulteration, substitution and tampering. The Global Food Safety Initiative (2013) describes food defense as "the process to ensure the security of food and drink and their supply chains from all forms of intentional malicious attack including ideologically motivated attack leading to contamination or supply failure". BRC (2015) considers food defense as the procedures adopted to assure the safety of raw materials and products from malicious contamination or theft whilst FDA (2017b) defines it as "the effort to protect food from intentional acts of adulteration where there is an intent to cause wide scale public health harm". Recent literature has sought to create a typology for food defense to aid its assessment and mitigation (Manning, 2019). Therefore, in theory food defense concerns now sit outside the HACCP process, as these intentional contaminants are distinct from food safety hazards (Manning \& Soon, 2016a). However, in practice within food businesses, the identification of areas that are vulnerable to food fraud and/or may require food defense countermeasures may involve the same personnel as those who implement HACCP and thus there is potential for confusion for organizations on where HACCP processes sits within wider aspects of food safety, food defence and food crime (Yoe \& Schwartz, 2010; Wiśniewska, 2015). This may be exacerbated by the use of similarly named systems of control, e.g. threat analysis critical control point (TACCP) and vulnerability analysis critical control point (VACCP) methodologies (Manning \& Soon, 2016; Manning, 2019). Ultimately, as Kleboth et al. (2016) summarize, in ever more complex food supply chains, scandals and incidents persist and concerns over food safety, authenticity and wider aspects of food integrity mean that multi-layered private and public standards have evolved and these interact with the HACCP approach in a transactional approach to ensure food safety. These generic and often third party standards follow a risk reduction approach that seeks to consistently deliver safe and legal food and prevent harm to individuals and prevent organizational or reputational damage. Thus, regulatory bodies and food manufacturers recognize that undertaking hazard analysis and developing an associated FSMS alone does not deliver zero food safety risk in food supply chains and that additional, agile mechanisms need to be in place. The need to verify implementation of 
FSMS means that there needs to be more focus on the associated FS-Culture. However what cultural factors are of influence that drive compliance with such public and private standards?

\section{Compliance approaches to food safety using food supply chain standards}

\subsection{Evolution of food supply chain standards}

Increasingly, the impact of food safety failures on consumer health, reputation damage, confidence loss, and future sales, and associated safety and quality standards have gained wider interest in the food supply chain (Fulponi, 2006). Multiple terms about standards exist and for ease of differentiation these has been synthesized (Table 1) so they can be referred to in the paper.

\section{Take in Table 1}

As required by their stakeholders (e.g. government, retailers, customers), and often as a pre-requisite to either operating the business and/or as a means of accessing specific markets, companies use both public and private product and process standards to provide the basis upon which to design their food safety programs. In this context, the food safety program is considered to be the written document indicating how a food business will assure that food safety hazards associated with food handling activities of the business are effectively controlled (Luning et al. 2008, 2009; Jacxsens et al. 2015). Private standards are commonly stricter in terms of requirements than the public standards established in local legal frameworks (Fulponi, 2006), i.e. they go beyond legislative compliance or 'safe to supply' and include the adoption of additional requirements and standard elements. Compliance with these private standards by a potential supplier is often a pre-requisite to market access i.e. if the organization cannot demonstrate compliance with these food safety standards then they cannot supply. Therefore, food business operators (FBO) translate these stakeholder requirements into their specific food safety programs and adapt the requirements of given system standards to their particular food business context (Luning et al. 2009, 2011a; Kirezieva et al. 2013). This strategy then frames, shapes and affects the actual FSMS that is adopted and its ongoing performance (Herath, Hassan \& Henson, 2007; Luning et al. 2011b; Luning et al. 2015; Kirezieva et al. 2015a). Since the 1990s, the number of private third party standards has increased substantially (Table 2). This is due in part as a reaction to multiple food safety incidents and a need to regain consumer trust, developments in 
product liability law, and the limited capacity of public bodies (Fulponi, 2006; Schulze, Albersmeier, Gawron, Spiller, \& Theuvsen, 2008).

\section{Take in Table 2}

From a market perspective, imposed retailer requirements, reduction of transaction costs, mitigation of supply chain risks, and to a lesser extent productivity and efficiency improvement have also stimulated the adoption of private standards by food organizations (Fulponi, 2006; Schulze et al. 2008; Spadoni, Lombardi, \& Canavari, 2013; Latouche \& Chevassus-Lozza, 2015). Indeed there are multiple drivers for standards development and adoption and also barriers to their adoption too (Figure 4). Private standards, such as the BRC Standard, IFS-Food, GLOBALG.A.P, SQF, and the Foundation for Food Safety Certification, (FSCC2000), have been widely adopted by the European food industry (Schulze et al. 2008; Herzfeld, Drescher, \& Grebitus, 2011; Spadoni et al. 2013), and beyond at a global scale (Herzfeld et al. 2011). Particularly in emerging countries with poor institutions and legal frameworks (Henson \& Humprey, 2010), private standards can support design and operation of FSMS and create access to global markets (e.g. Kirezieva et al. 2015a, 2015b; Kussaga, Luning, Tiisekwa, \& Jacxsens, 2015; Nanyunja et al. 2016) or address the governance void for organizations seeking to extend their operation to those countries. The interplay between regulation and private food standards with regulation evolving from a 'one size fits all' to risk based-regulation is leading to a hybridization of food governance between public and private instruments (Verbruggen \& Havinga, 2017a), which impacts FSMS design and operation (Kirezieva \& Luning, 2017). Hybridization of food governance has occurred in two distinct dimensions: firstly the national and international dimension with the interplay of public governance and institutions such as Codex or the International Standards Organization (ISO); and secondly between government, producers and third-party organizations (Zhang, Qiao, Wang, Pu, Yu \& Zheng, 2015; Verbruggen, 2016; Verbruggen \& Havinga, 2017b; Zhu, Huang \& Manning, 2019).

\section{Take in Figure 4}

The role of the state and the role of the market can often be fluid, which suggests that there is dynamic coupling of societal and institutional risks, as described by the theory of risk colonization (Rothstein, Huber 
\& Gaskell, 2006). Prevalence of certification of private standards seems more likely in developed markets and food economies especially in countries with established trade relations with other countries or trading blocs, such as the EU where these standards have been developed and adopted for some time (Herzfeld et al. 2011). Since 2005, most of the private standards previously described have evolved rapidly and, through industry input and an iterative approach, new versions are launched on a regular basis (Table 2). Development and modification of these standards sometimes reveal a mosaic approach where owners and developers of private standards take elements from different standards such as CAC Standards or ISO standards and integrate criteria with specific elements that address supply chain actors' concerns with regard to a given food safety or other supply chain risk. Common tendencies observed in the evolution of private standards are an increase in strictness and a more prescriptive character in the discourse that surrounds the requirements, and the continuous addition of new clauses, sections, and modules (Table 2). Examples of this are the requirement for the use of HACCP as a baseline and the increasing numbers of additional risk assessments in the BRC Global Food Standard version 7, including that of the vulnerabilities associated with food crime and the inclusion of a clause on FS-Culture in version 8. Furthermore, various scheme owners (e.g. IFS, GLOBALG.A.P, and BRC) introduced multiple new system standards for other (or upcoming) actors in the food supply chain, such as catering, packaging suppliers, food stores, distribution centers, and global markets (Table 2).

Some standards (e.g. SFQ and GLOBALG.A.P) have modular approaches to enable "new entrants" to third party certification to allow organizations to sequentially advance the depth and scope of their FSMS i.e. the standard owners have a baseline "fit to supply" level standard as well as a higher level standards within their overall portfolio. The first iterations of the BRC standard (e.g. 1997) also had two levels: foundation and higher level and recommendations for good practice. For the same reason, in some countries local versions of GLOBALG.A.P standards were developed, like JapanGap, ChinaGap, MyGaP (Tey et al. 2016). Table 2 shows the increasing requirements of schemes with regards to verification activities and, therefore, auditor competences have become more formalized and rigorous, which leaves less room for nuanced interpretation and application of private standards in view of the specific business context. There has also been increased focus on 'managerial' requirements, such as senior management commitment, training, policy setting, and competence requirements, and recently attention is also given to 
FS-Culture and unethical or illicit behavior. All these developments have contributed to a proliferation of elements and requirements within a given system standard often leading to extensive "checklist-based" approaches to product and system verification (Powell et al. 2011; Manning, 2018a).

\subsection{Challenges associated with third-party certification}

Whilst there are advantages to using a checklist type approach in terms of auditor consistency, conversely this approach can cause "audit fatigue" (Petersen, 2009; Martz, 2010). Auditor fatigue will decrease the reliability of the verification activity and due to the rigid application and non-reflective use of a checklist can also drive "evaluation myopia". This also may lead to an inability of the auditor to identify side effects or side impacts during the audit i.e. they have a linear rather than a holistic auditing approach (Martz, 2010; Manning, 2013, Manning \& Soon, 2014, Manning, 2018a). Even though checklist based auditing might be technically correct, there may be no incentive for the auditor to identify wider material weaknesses or deficiencies in the FSMS (Flores-Miyamoto, Reij \& Velthuis, 2014). Indeed, the considerable resources employed in developing manuals, guidebooks, protocols, and checklists for audits are wasted when the contribution of such tools to audit efficiency and effectiveness is unclear (Leeuw, 2011, Läikkö-Roto \& Nevas, 2014). Albersmeier, Schulze, Jahn, \& Spiller (2009) differentiated between what they described as checklist governance and contrasted this with the concept of risk-based audit programs that ensure optimum and cost effective utilization of verification resources (van Asseldonk \& Velthuis, 2014). For micro and small sized organizations, the costs of demonstrating compliance with private standards can be challenging. Kleboth et al. (2016) proposed that complex systems risk-based auditing, rather than considering and increasing the amount of audit criteria and the level of detail or depth of audit, should focus on the identification, analysis and evaluation of evidence-based, actual, pressing and emerging systemic risks. As a result, such verification is more effective in determining the current state of the FSMS.

In practice, food quality managers indicate that reactive, stricter and more specific requirements do not necessary lead to better performance of the FSMS (Kleboth \& Strasser, 2013). The multiplication of certifications, the overlap in standards, the difficulty to integrate all standards in a given organization's FSMS, and the inconsistencies in food product standards mean that many food supply chain actors suffer "audit fatigue" with regard to private standards resulting in the rising costs of assurance whilst retail prices remain stable (Sonntag, Theuvsen, Kersting, \& Otter, 2016). As previously described, the commonly used 
private standards in the food supply chain, have a typical checklist compliance based structure and it can be argued that due to the reactive nature of private standards' evolution, issues are often addressed in multiple sections potentially leading to duplication and confusion. Moreover, the structure and elements included in private standards are not necessarily based on scientific concepts or quantitative risk assessment and as a result can seem arbitrary, especially where they are addressing an issue where the food safety risk to consumers is deemed as negligible (see also Monaghan et al. 2017).

Other challenges that have been associated with private standards are the limited flexibility allowed in the auditors' approach towards different situations that may arise within the organization, and the continued requirement for retailer driven supplier auditing, even though the organization may hold current, valid third party certification (Spadoni et al. 2014). If the private standard is very detailed with multiple clauses that need verification during an audit this may result in lower auditing quality in the longer term due to time pressure. Audits are only ever a 'snapshot' of actual performance (Powell et al. 2011) and third party certification relies on the organizational integrity of the auditee organization to reflect their daily practices during the audit. Moreover, the commercially driven limit on the time available to undertake the audit also results in frustrated companies that may have to meet/fulfill system standard requirements that do not make sense for their particular context or where, in their particular situation, the risk the standards are seeking to mitigate is minimal (Albersmeier et al. 2009; Kleboth et al. 2016).

However, some organizations may be happy to comply with a prescriptive private standard because they are simply willing to allow others to make decisions for them. This can result in reduced agency and influence the degree of organizational engagement with the derived FSMS. The more prescriptive style of standard, aimed at supporting small and medium sized enterprises (SME's) to facilitate the implementation of private standards is a form of paternalism. Prescriptive paternalism shifts the sense of ownership of the FSMS from having the full engagement of the organization's management and staff to develop appropriate protocols to meet the needs of the organization, and instead accepting a FSMS development and implementation approach that can be described as a "line of least friction" application or a cost-benefit trade-off. Decisions in this context on how a FSMS is developed and implemented are affected by the dynamic aspects of the given task environment such as multi-level trade-offs, time pressure, weak feedback on the effect of management actions, the level of uncertainty, and perceived risk (Kerstholt, 1994). 


\subsection{Risk-based standards and transformational management}

The only private standard that uses the widely acknowledged iterative "process approach" rather than the prescriptive-approach just described is ISO 9001. The process approach concept is clearly grounded in science-based management principles. The fully restructured 2015 revision (ISO9001: 2015) evolved into a high level structure of the Plan-Do-Check-Act (PDCA) cycle (based on Deming, 1986) and allows for more tailored translation of requirements by explicitly acknowledging the business context with its typical internal and external challenges, focused on both risks and opportunities. Indeed an Annex of the ISO 22000: 2018 Standard for food safety management systems cross references between Codex HACCP principles (Codex 2009) and the requirements of the standard and includes the PDCA cycle approach and the interrelationship with HACCP. Panghal, Chhikara, Sindhu \& Jaglan (2018) assert that ISO 22000 embeds HACCP in a form that leads to a more effective and auditable FSMS that includes the need for continuous improvement.

Prescriptive private standards, on the other hand, via their rigid structure and emphasis, may favor and/or create a reactive rather than a proactive mentality (culture) in those organizations seeking to implement the said standards. As the certificates (linked to the standards) are a form of "license to produce", this then directly affects market access for individual organizations. This framing of third party certification may shift ownership of the need for compliance within the organization from being proactive and strategic to reactive and tactical. Across global supply chains, organizational motivation to gain certification may reflect a spectrum of cultural approaches to adopting the standards, systems and protocols required for regulatory compliance and to demonstrate compliance with procurement pre-requisites to supply.

Commonly, food industries tend to implement supply chain standards in a transactional rather than a transformational way (Manning, 2017b). The transactional approach is often simply a technical goal and compliance driven, demanding that staff work according to prescribed requirements such as specifications, work instructions and procedures and determines appropriateness through prescribed compliance audits and other verification activities (Manning, 2017b). Transformational management is more culturally orientated and reflects activities to empower staff to implement system requirements and to "feel" that compliance is important, in fact essential, as most private standards drive the visual, concrete formalization of FSMS through requiring protocols, procedures, and associated compliance documentation; the element 
that is most often used for verification. A prescriptive approach to developing and implementing private standards has been considered here, but a third approach is posited by the authors i.e. using a more holistic and cultural framing of the FSMS. Whilst a move away from compliance (checklist) based system design and verification to an outcomes based approach is of value, there are obvious concerns about bias being introduced and a lack of consistency of how standards are verified across the food supply chain. In a more risk-based, situational and targeted approach to verification, there is a drive for efficacy and efficiency and for continuous improvement in both the design and implementation of FSMS and in the third party certification process itself (Albersmeier et al. 2009). Developing third party verification approaches into the future to become more outcomes-based or to use multiple sources of data is an emerging theme in the literature. The use of triangulation allows for comparison between different sources of evidence, especially in complex, socio-technical situations by counterbalancing the strengths and weaknesses of different methodologies and approaches and in doing so increase the credibility and depth of audit processes (Yeasmin \& Rahman, 2012; Carugi, 2016; Jespersen \& Wallace, 2017; Manning, 2018b; De Boeck, E., Jacxsens, L. Vanoverberghe, P. \& Vlerick, P. 2018). This line of enquiry then gives rise to some questions. Does this result in the organization simply honing its FSMS to meet a set of prescribed and specific standard(s) rather than reflecting on the bespoke challenges associated with the food they produce and developing an FSMS that is situationally appropriate and valid? If instead, the FSMS design is driven by the need to comply with private standards that are specific, static/rigid, with strict/prescriptive requirements, is there then a trade-off taking place? As a result of this trade-off does the organization lose staff buy-in, a sense of ownership, and then as a result carry reduced operability and practicability within the resultant FSMS they implement?

The argument put forward here is that the design of private standards should be flexible enough that the organization can comply, and gain continued certification, through tailoring and allowing their FSMS to continually evolve to meet the dynamic requirements of the product, process, and the internal and external characteristics associated with the organization. Therefore, rather than simply a hazard-based transactional approach to food safety management, should organizations follow a more transformational systems-led and risk-based approach and as a result focus more on realizing the minimization of food safety risk in a given situation and context? A more holistic approach to food safety is now presented. 


\section{Holistic approaches to food safety and developing FSMS}

628

\subsection{Risk and Context}

Perceptions of risk, held collectively or individually by stakeholders and actors in the food supply chain, including consumers, influence how FSMS are developed and implemented, as well as the degree of actor engagement with the processes that are required to ensure food is consistently safe and wholesome (Manning \& Soon, 2016b). It is important to recognize that risk is being considered here and in the supply chain context, as previously outlined, this largely determined in a qualitative, or semi-quantitative approach that is framed by uncertainty, and ambiguity. Higher order systems driven by the interaction of regulation and enforcement surveillance and the interaction between international and national policy and associated market governance are interwoven and complex (Manning \& Luning, 2018). Luning and Marcelis (2006) describe these higher order systems as chaotic, having greater ambiguity i.e. lack of clarity about the mechanisms of influence and uncertainty due to lack of information. As a result, such systems have less linearity, rationality and stability. Vulnerability, uncertainty, and ambiguity are inherent attributes of internal and external organizational context factors, such as product and production related characteristics of the environment in which a FSMS operates (Luning \& Marcelis, 2007, Luning et al. 2011a). Internal and external context factors influence the degree of risk associated with food products, processes and the associated public and private standards developed to mitigate such risk (Manning \& Luning, 2018). In addition, context factors can be active i.e. influencing the organisation on a continuous basis or alternatively dormant awaiting a trigger factor that will then enact them. Luning et al. (2011a) distinguish four main context factors, which can affect control and assurance activities in a FSMS (Luning \& Marcelis, 2007; Luning et al. 2011a; Kirezieva et al. 2013; Manning \& Luning, 2018):

- Product characteristics i.e. the intrinsic properties of initial materials and final products.

- Production characteristics i.e. the extrinsic conditions utilized during primary production, processing, or handling.

- Organisational characteristics specific to the organisation itself. These can be further subdivided into individual (people) characteristics, group characteristics (transformational characteristics 
associated with food safety culture and quality culture), organisational structures (transactional division of tasks, responsibilities, rules, procedures), and information systems, which affect peoples' decision-making behavior (see De Boeck, Jacxsens, Mortier \& Vlerick, 2018); and

- Chain characteristics i.e. the conditions during supply, and relationships within the supply chain. Context factors are characteristics of a system environment that can affect its performance and cannot be (easily) changed (Kirezieva et al. 2013:109). More specifically, FSMS context factors are situational, structural elements in the FSMS that affect decision-making activities and as a result the output derived (Luning et al, 2011), and can be further characterized as narrow and broad context factors, or internal and external business characteristics (Table 3).

\section{Take in Table 3}

External context factors that exert influence from the broader context include supply chain, sociopolitical, legal and national factors (Kirezieva et al. 2015b). These are also called macro factors by Nayak and Waterson, (2016). Internal (or narrow) context factors include product, production, and organizational characteristics (Luning et al. 2011a; Kirezieva et al. 2013), and from a systems viewpoint are termed meso factors with the individual being the micro level (Nayak \& Waterson, 2016). It is important to recognize that the context in which the FSMS operates is narrower than the overall operating environment (broad context) of the organization. The external environment can encompass wider context factors that can still affect overall food safety output and delivery of safe food (Luning et al. 2011b, Kirezieva et al. 2015b). Using a process (input-activity-output) approach, triggers can be described as the inputs/influence on an organization that arise from the business environment, either internal or external to the organization. Extrinsic triggers can be initiated and driven by a range of supply chain actors and wider stakeholders and include changes in customer requirements that influences intrinsic and extrinsic product characteristics which in turn may have an impact on food safety, for example reformulation of products to reduce salt and sugar levels. Triggers can influence an organization singularly or in consort, harmoniously or in discord. The impact of the combination of individual or concerted internal and/or external triggers is to create organizational and wider supply chain uncertainty. It can be postulated that internal trigger factors include changes such as new production systems, technology, and new individuals in key management positions. 
Examples of potential internal and external triggers have been synthesized (Table 4).

681

682

683

684

685

686

687

688

689

690

691

692

693

694

695

696

697

698

699

700

701

702

703

704

\section{Take in Table 4}

The structure of the organization and the associated FSMS will be specific to the given business i.e. it can have either a central focus of food safety control or a more decentralized hierarchy (Luning \& Marcelis, 2009). The interactions of strategic, tactical, and operational decision-making are as a result, situationally framed. Moreover, the hierarchy of decision-making and given determination of food safety "meaning" has a strong influence on the culture that surrounds the FSMS and thus is worthy of consideration here (Nyarugwe, Linnemann, Hofstede, Fogliano, \& Luning, 2016).

\section{Take in Table 5}

Table 5 provides examples of the types of decision-making that occurs at these three levels within an organization: strategic, tactical, and operational. Nayak and Waterson (2017) argue that management and decision-making at levels of an organization matters in terms of FS-Culture stating that if senior management is too focused on profit generation, and this combines with a dissonance between senior management and employees then the result is a failure to set the example of a positive FS-Culture. Furthermore, social networks affect the efficacy of the FSMS. The overall food safety climate (FS-Climate) of an organization is the convergence of individual characteristics such as beliefs, values, and perceptions into group characteristics (De Boeck et al. 2015). Thus the socio-technical interactions that frame the development, validation and implementation of the FSMS are crucial to its efficacy and alternatively if there is a negative socio-techncial influence can underpin its vulnerability and potential failure too.

\subsection{Socio-technical systems}

Luning and Marcelis (2006) suggest that a techno-managerial approach with increased levels of information reduces uncertainty; and if as a result greater knowledge is instilled into individuals also reduces ambiguity. However, dynamic FSMS remain difficult to fully predict in terms of both human behavior and also product and production failure (Luning \& Marcelis, 2007). De Boeck et al. (2015) combine in their study, the techno-managerial route (based on Luning \& Marcelis, 2006, Luning et al. 2011a) to assess FSMS and 
also the individual human factors, as they influence the implementation of the FSMS. People in organizations interacting with the technological system create "socio-technical systems" (Bronfenbrenner, 1986; Bostrom \& Heinen, 1977; Ghaffarian, 2011; Winter, Berente, Howison \& Butler, 2014). It is important to recognize that FSMS are not operating in isolation, instead they are an element within wider organizational and supply chain socio-technical systems, and the influence of internal and external triggers means that they operate in a situational business/environment context that can set boundaries on the design, application and implementation of the FSMS i.e. the socio-technical system can be multi-level. Further, effective FSMS require the embedding of systems thinking and a clear acknowledgement and understanding of the complexity of the socio-technical systems that provide the context in which they operate (Kirezieva et al. 2015a; 2015b). Nayak and Waterson (2016) analysed the causes of two foodborne outbreaks rooted in six system levels, which together shape the socio-technical system in which an organization and its FSMS operate:

1. Government level: Where regulation is developed to control food safety.

2. Regulatory bodies and association level: Where regulation is translated into industry rules and standards designed to address food safety.

3. Organizational level: Where the industry rules and regulation are integrated into the organizational and situational rules and policies.

4. Management level: Where the staff activities and roles are specified and overseen with reference to the organizational level rules and policies.

5. Staff level: Where the staff or work force are required to follow the rules set by their managers, and

6. Equipment and surroundings level: Where the organization's situational rules and policies are applied to ensure compliance with government regulations, industry rules and standards and organizational rules and policies.

Further, using this approach means there needs to be a shift from hazard-orientated (particularly 
microbiological hazard-oriented) food safety management approaches to a more holistic socio-technical approach that address the causes of food safety issues that occur at each level (Nayak \& Waterson, 2016) and it could also be argued at the interfaces between different levels (Manning, 2017b; Jespersen et al. 2019). Indeed, perceptions of food safety risk at the organizational level are neither quantitative nor necessarily a 'qualitative approach based on expert opinion' (Monaghan et al. 2017). In reality, food safety risk assessment at the organizational and supply chain level is influenced by perceptions, social norms, and constructs of meaning. Thus, the role of these cultural influences on FSMS design and application cannot be ignored.

\section{3 influence of FS-Culture and FS-Climate}

Social representations drive collective meaning-making and common recognition produces social bonds based on dialogues, discourse, emotions, attitudes, and judgments that unite organizations and groups (Höijer, 2011). Thus, social representations bound the implementation of FSMS and the associated decision-making that occurs. Worldviews are the social, psychological, and political factors that influence an individual's risk judgments (Slovic, 1999) and thus are of importance when considering individual and collective perceptions of food safety risk and its meaning both to consumers and to individuals that work within food businesses throughout the supply chain. Worldviews are generalized attitudes towards the world and its social organization (Peters, Burraston \& Mertz, 2004); or the shared mental representations, values and general social, cultural and political attitudes held by a group of individuals (Leiserowitz, 2003). Van der Linden (2015) considers the concept of "values" as differing from worldviews in two ways: firstly, that values precede worldviews and secondly that values are guiding principles with greater specificity and are more stability than worldviews. These socio-cultural factors can influence the organization in terms of how people interact with complex systems and context factor characteristics and the need, on occasions, to make decisions based on limited information. In this circumstance, meaning is an important personal construct that links people to their environments and as a result influences their perception of a given function or activity (Rapoport, 1988; Coolen \& Ozaki 2004) and potentially their perception of a given food safety risk. Translating from their original subject area to consideration of food safety, Rapoport's (1988) three levels of meaning suggests that: high-level or macro meanings are related to worldviews, heuristics 
and philosophical systems for example consideration of the cost of implementing the FSMS versus the benefit derived; middle level or meso meanings convey latent functions such as group identity, status, wealth, power, and are represented via organizational structures and hierarchy within a given business; and lower-level or micro meanings are everyday and instrumental meanings and identity as perceived by the individual. In all organizations an informal, often invisible, system derived from these cultural aspects operates alongside the formal visible processes of the FSMS (see the work of Schein, 1985; Griffith, 2014 and others). Interpreting the FS-Culture levels of Griffith (2014) suggests that each organization e.g. a food manufacturing business, will be unique in terms of the exact combination and interaction of these levels of organizational culture and as a result this will influence the effectiveness of the FSMS (Manning, 2017b).

Culture as a construct describes the emergent history and traditions that give meaning to the underlying values and beliefs held by members of formal and informal social groupings (Buchann \& Huczynski, 2004; Griffith, Livesey \& Clayton, 2010). For any given organization there will be a distinct set of values and beliefs (Powell et al. 2011) that form a heterogeneous rather than singular framing (Griffiths et al. 2010) that is described in the context of this paper, specifically as FS-Culture. FS-Culture is defined as shared values, beliefs and norms that affect mindset and behavior toward food safety in, across and throughout an organization (GFSI, 2018). Griffith (2014) described three levels of FS-Culture:

Level 1 - Food safety climate (FS-Climate): the outermost layer of food business culture that is considered during verification, auditing and inspection activity and is observable (Griffith, 2014). This level of FS-Culture can be modified depending on the situation and the internal and external conditions or constraints e.g. lack of resources, people, or an event such as the presence of the auditor/inspector. De Boeck et al. (2015) describe food safety climate as the relative priority or the "meaning" given to food safety in an organization or work unit as perceived individually or collectively by employees.

Level 2 - Underpinning culture: the middle layer includes the organization's espoused values (often unspoken) and guides the employees' behavior and attitudes to authority and legislation. Depending on the depth of verification activity, this level of culture can be examined and measured.

Level 3 - Core culture: the innermost layer that contains all the beliefs and assumptions by staff as individuals or groups about what the organization stands for. This level includes core values that are 
784

785

786

787

788

789

790

791

792

793

794

795

796

797

798

799

800

801

802

803

804

805

806

807

808

809

810

811 invisible and often assumed. Depending on the depth and scope of any verification activity this level may remain hidden.

Nayak and Waterson (2017) summarize the difference between FS-Culture and FS-Climate as FS-Culture referring to behavioral aspects i.e. what people do; and also the situational aspects of the organization i.e. what the company has in terms of products, processes and facilities; whilst FS-Climate refers to the psychological characteristics of employees in an organization i.e. how people feel and the meanings they derive with regard to food safety. FS-Climate is alternatively defined as the employees' (shared) perceptions of leadership, communication, commitment, resources and risk awareness concerning food safety and hygiene within their current work organization, however the construct is more temporal and subjective than representing the individual employee's perception of an organization (De Boeck et al. 2015, 2018). Third party verification activities can only ever capture a "brief glimpse" of the FS-Climate and, to date the third party audit approach has not been developed to assess FS-Culture specifically. However, a requirement for objective evidence of planning for the continual improvement of FS-Culture is being introduced into private standards (BRC, 2018).

Sub-cultures are separate from the dominant, overarching culture and can be categorized functionally (Hofstede, 1997), geographically (Hofstede, 2001), nationally (Hofstede, 2001; Jespersen \& Huffman, 2014) or by the collective identity or values that are shared by the members of the sub-culture (Khatib, 1996). In addition, contingency situations, such as product failure, increased orders, or inadequate training can influence the interfaces between sub-cultures, causing competitive interaction, barriers and conflict to occur especially where primary values and worldviews within sub-cultures are not congruent across the organization (Manning, 2017b). Functional interfaces such as those between quality and production; production and engineering; production and finance; production and procurement all influence both the formal and the informal aspects of an organization's FS-Culture. Indeed, Jespersen et al. (2019) propose a dynamic model of food safety culture based on the building blocks a) organizational effectiveness, b) organizational culture norms, c) working group learned and shared assumptions and behaviors and $\mathrm{d}$ ) individual intent and behaviors, and highlight the integration of and the interactions between these building blocks as crucial to the necessary maturation of FS-Culture. Multi-level interactions and interfaces may be visible during the monitoring and verification activities undertaken to measure the 
812 FS-Culture maturity and effectiveness, but equally may also be translucent or invisible during formal 813 processes such as an external audit (Manning, 2017b). The formalization of food safety controls and 814 management systems evolve from the FS-Culture and FS-Climate in a given organization and thus the FS815 Culture frames and, depending on its level of maturity, enables the FSMS. Conversely a weak FS-Culture would be expected to restrict the efficacy of the FSMS, but further empirical research is needed to support 817 this conclusion. The mechanisms of both formalization and informal drivers are considered in various 818 studies (e.g. Nyarugwe et al. 2016; Manning 2017b; Nyarugwe, Linnemann, Nyanga, Fogliano, \& Luning, 819 2018). Therefore, developing FSMS in isolation without regard for the perceptions and meaning of food safety, FS-Culture and FS-Climate, or sub-cultures within that organization is of limited value. Whilst FSMS

821 are formally developed to address the requirements of public or private standards and/or the context of a specific business setting they may firstly be inappropriate for the FS-Culture or FS-Climate in the given organization and secondly may not be effectively and consistently implemented throughout the 824 organization.

Moving from a static approach to food safety management (i.e. focused on system elements and product and process compliance with prescribed standards) to a more dynamic, holistic and risk-based approach with a focus on the interactions and dynamics of the organization itself requires new forms of socio-technical systems thinking. The cultural and behavioral factors associated with the people employed in the organization means that primarily the organization must truly understand itself in terms of structure, and internal and external triggers, which are often specific to its activities. Most importantly, the meaning of food safety within the organization, which is far more nuanced than simply undertaking hazard analysis, and defining risk appetite, risk management and mitigation, must be defined and understood. This holistic approach extends beyond the narrow use of HACCP principles and the development of a food safety plan;

834 is mediated by both internal and external triggers, which are constantly evolving and changing; and is framed by contextual factors that are specific to the organization and its wider supply chain. A static FSMS and associated FS-Culture will be limited with its modus operandi in terms of addressing and mediating the uncertainty and ambiguity associated with ever changing food safety risk. Whilst seeking to measure and determine FS-Culture is important (Emond \& Taylor, 2018; Nayak \& Taylor, 2018), there are however challenges to assessing FS-Culture effectively in practice (Nayak \& Waterson, 2015; Jespersen et al. 2017; 
Jespersen \& Wallace 2017; Nyarugwe at al., 2018; Kane, Taylor \& Teare, 2018; Taylor, Caccamo, Daniel \& Bulatovic-Schumer, 2018; Taylor \& Rostron, 2018). The conceptualization of a holistic view of the FSMS is therefore much more multi-layered and nuanced than the simple development of PRPs, OPRPs, and identifying and managing process CCPs for food safety. A failure to implement a systems based approach means the use of private standards will continue to be a shallow, rather than a deep form of implementation and verification with associated limitations in the ability to deliver in terms of reducing the likelihood of food safety incidents. However, it is questionable what supply chain incentives exist for a more thorough evaluation and adoption of the holistic approach, e.g. by deepening third party certification, supplier, and internal audits and by augmenting these with valid FS-Culture measurement systems. The hybridization of food governance and retreat of regulatory mechanisms in favor of private standards and earned recognition should mean that private verification mechanisms will be driven to be deeper and more holistic in nature. However, the exact combination and form that these mechanisms need to take is yet to be determined and further research is needed both to establish the precise nature of this holistic culture-systems-practice approach and how to assess maturity and effectiveness of the associated holistic FSMS and FS-Culture.

\section{The evolution of FSMS - where next?}

Food companies operate in an increasingly complex highly interdependent food supply chain network and face multiple challenges associated with developing, implementing and verifying their FSMS in order to effectively manage food safety. Varzakas and Jukes (1998) argued that globalization has driven global integration and standardization of markets and complex interdependence that has then led to the emergence of isomorphism in structures, attitudes, and norms especially within transnational corporations. Manning, Soon, de Aguiar, Eastham and Higashi (2017) noted that the concept of supply chain pressure has increasingly emerged within supply chain literature over the last decade especially the notion of integration and greater isomorphic pressure (DiMaggio \& Powell, 1983; Delmas \& Toffel, 2004; van Plaggenhoef, 2007; Sarkis, Zhu \& Lai, 2011; Gimenez, Sierra \& Rodan, 2012; Esfahbodi, Zhang, Watson \& Zhang 2017; Manning, 2018c). In essence, homogenization, or isomorphism, creates and spreads a common set of values, norms, and rules, which then results in similar practices and organizational structures (Othman, Ahmad \& Zailani, 2009) often driven by a need to conform not only to the external 
868

869

870

871

872

873

874

875

876

877

878

879

880

881

882

883

884

885

886

887

888

889

890

891

892

893

894 environment, but also the context that the environment itself promotes (Czinkota, Kaufmann \& Basile, 2014). Indeed, isomorphism occurred in the work to establish international HACCP guidance through the 'invisible college of HACCP experts (Demortain, 2007, p9) and can be seen as a natural effect of the comments and critical review cycles that form the step procedure for elaborating Codex Standards (FAO, no date a \& b) and within the consensus approach of industry benchmarking of private standards, as undertaken through both GLOBALG.A.P activities and the work of the Global Food Safety Initiative (GFSI). The process of benchmarking itself can drive isomorphism as private standard owners seek to demonstrate private standard equivalence. Therefore, both the resultant organizational FSMS and FS-Culture that are informed by these standards are influenced a series of rational myths. Institutionalized rules, and norms, and increasingly the structural similarity of private standards creates contiguous cultural myths, symbols, rules and regulations (see DiMaggio \& Powell, 1983) across the food industry.

Customer pressure for a supplying organization to use a certain third party private standard or the customer's own standards requirements further complicates the picture. This supply chain pressure of compliance can result in a transactional approach that seeks to develop an FSMS to meet the required standards rather than because it is the right approach for the products manufactured and the processes employed, and the right way to protect the consumer. Indeed the drive for compliance and to eliminate deviance may weaken FSMS in the future. The deviance of employees from organizational norms can have negative outcomes for the organization, but can also be a form of constructive deviance that is beneficial and leads to positive change that drives innovation and entrepreneurship in food safety management as products, systems and processes (Spreitzer \& Sonenshein, 2003; Galperin \& Burke, 2006). Questions remain as to whether the current transactional industry approach to managing food safety is sufficient. Nevertheless, further research is needed to establish what a more systems and risk-based holistic food safety management framework would look like, how it would address both formal and informal aspects of FSMS and FS-culture and how it would work in practice within food organizations. The reactive mindset of managing as a result of external triggers is well established and further clarity is needed about the roadmap to develop a more proactive mindset that is dynamic enough to meet the needs of a given organization and wider supply chain. 
Organizations are experiencing greater proliferation of private standards and the implementation of ever more requirements, standards and additional protocols, but it is unknown whether this transactional, compliance-driven supply chain approach can actually lead to better (predictable and consistent) product safety; in fact it is proposed that a saturation point has been reached (Kleboth et al. 2016) and the food sector may be facing a simple process of ever diminishing returns. Kleboth et al. (2016) describe this approach as the 'reactive food control vicious cycle'. This situation is caused initially after a food incident when the degree of mistrust in the food industry increases and then, depending on the degree of personal and financial impact of the given food safety incident, there is pressure from food chain actors and stakeholders to implement appropriate corrective actions. Consequently, to avoid incidents in the future, more and/or stricter standards are required; and then the cycle starts over again when a new food scandal occurs. This approach could also be called "protocolization", i.e. the formalization of organizational operations as a response to minimizing issues of blame and liability (Hood \& Rothstein, 2001); and increasing bureaucratization (DiMaggio \& Powell, 1983).

Rothstein et al. (2006:97) assert that assessment of risk is "a way of formalizing organizational operations in order to provide bureaucratically rational 'due diligence' defenses in the face of increased accountability pressures." Due diligence in itself drives the complexity and scale of risk elimination and risk management approaches (Manning \& Luning, 2018). As has been explored in this paper a risk assessment is a much more in-depth and quantitative approach when compared with the process of hazard assessment. Thus food safety risk assessment extends beyond the use of HACCP as a tool to develop, implement and verify a FSMS. The construct of HACCP uses hazard analysis as a transactional tool to determine the likelihood and severity of food safety hazards at the food business level and to identify the measures that can be implemented to reduce the likelihood of occurrence or the severity should they occur. In wider business literature, risk is described as a combination of the probability of an occurrence of a particular threat and the possible subsequent impacts (Slovic, 2002); or as a measure of a hazard that can result in 'threat to people and what they value' (Kates \& Kasperson, 1983). Whilst there are clear similarities between these definitions, there are also differences in the way that risk is being expressed and this suggests there is an inherent meaning to an individual or group associated with the qualitative determination of risk. Therefore, risk is determined through a politicized process and contextualized as a social construct 
923 (Masuda and Garvin, 2006) influencing at the supply chain level who manages, mitigates, reduces or 924 outsources any given risk. Managing risk in a holistic way is an integrative process where different actors 925 may bring their different interpretations of risk but the focus on the interactions and dynamics of the 926 organization and its environment is to consistently produce safe and legal food. Thus understanding the 927 cultural aspects that frame food safety risk assessment is crucial to ensuring that the systems used are 928 appropriate, valid and effective. The food industry is recognizing the importance of FS-Culture and the 929 necessity to consider at the food organization level how FS-Culture informs and frames the perceptions of 930 food safety risk and the implementation of FSMS and PRPs. Understanding the prevailing FS-Culture and 931 how, where it is necessary, to improve it remains a key challenge for every organization.

932

933

934

935

936

937

\section{Conclusion}

The concept and factors that influence the structure of FSMS in individual organizations has evolved over the last 75 years. Key milestones include the international acceptance of HACCP principles and their application in food businesses to develop appropriate, valid and effective FSMS. However the application of HACCP principles is not without its challenges and retrospective investigation and analysis of foodborne illness data demonstrates that HACCP systems are not always working effectively in practice. HACCP principles have been one of the cornerstones of the development of private food safety standards, but these standards have tended to evolve in a mosaic way, with new topics and requirements being added each time they are revised. This can result in standards that are prescriptive and inflexible and drive the development of a least cost FSMS rather than the development of an appropriate outcomes based food safety system. This mindset has led not only to questions about where this trend will end but also has led to a type of food safety management in food organizations that is more transactional and compliance driven than transformational and having cultural maturity. The realization that FSMS cannot be stand-alone technical systems but are part of and impacted by the social context within which they operate has been an important driver for evolution. Research has led to the cultural framing of FSMS through better understanding of the FS-Culture and FS-Climate constructs. As these academic approaches cascade down to the development of private systems standards this should allow further enhancement of food safety performance and also industry mechanisms for verification of FSMS. 

research, but further work is needed to establish how FSMS, practices and culture relate to and interact

953 with each other at multiple system levels, and at cultural interfaces in order to reveal a model of the risk954 based holistic approach to food safety management that can be widely adopted and inform better food 955 safety management in the future.

956

957 8. Author Contributions (required for JFS original research manuscripts)

958 All authors designed and contributed to all the sections in the review. Initially each author concentrated 959 their efforts in specific sections: L. Manning, sections 1, 2 and 5; P Luning, section 4; C Wallace, section

960 3. The review then progressed through an iterative development process involving all 3 authors in 961 critically reviewing, extending and developing the initial drafts.

962

963 
964

965

966

967

968

969

970

971

972

973

974

975

976

977

978

979

980

981

982

983

984

985

986

987

988

989

990

991

992

993

994

995

996

997

998

999

1000

1001

1002

1003

1004

1005

1006

1007

1008

1009

1010

1011

1012

1013

1014

1015

1016

1017

\section{References}

Aladjadjiyan, A. (2006). Physical hazards in the agri-food chain. In P.A. Luning, F. Devlieghere, \& R. Verhe (eds) Safety in the agri-food chain (pp. 209-222). Wageningen Academic Publishers.

Wageningen Netherlands

Albersmeier, F., Schulze, H., Jahn, G., \& Spiller, A. (2009). The reliability of third-party certification in the food chain: From checklists to risk-oriented auditing. Food Control, 20(10), 927-935. DOI:

10.1016/j.foodcont.2009.01.010

Baş, M., Yüksel, M. \& Çavuşoğlu,T, (2007). Difficulties and barriers for the implementing of HACCP and food safety systems in food businesses in Turkey. Food Control, 18(2), 124-130. DOI:

10.1016/j.foodcont.2005.09.002

Bauman, H. E. (1993). The origin of the HACCP system and subsequent evolution. Society of Chemical Industry Lecture Series Paper No. 5 London.

Bauman, H. E. (1990). HACCP: Concept, development and application. Food Technology, 44(5), 156-158

Bauman, H.E. (1974). The HACCP concept and microbiological hazard categories. Food Technology. 28(9), 30-34, 74

BRC (2015), British Retail Consortium Global Standard Food Safety. Issue 7. BRC, London.

BRC (2018), British Retail Consortium Global Standard Food Safety. Issue 8. BRC, London.

Bostrom, R. \& Heinen, J. (1977). MIS problems and failures: A socio-technical perspective. MIS

Quarterly, 1(3), 17-32

Bronfenbrenner, U. (1977). Toward an experimental ecology of human development, American

Psychologist, 32(7), 513.

BS EN ISO 22000:2005, "Food Safety management systems - Requirements for any organization in the food chain" BSI London.

BS EN ISO 31000, (2018). Risk management - Guidelines BSI London

Buchann, D. \& Huczynski, A. (2004). Organizational Behaviour: An Introductory Text, 5th Ed., Pearson Education Limited, Madrid. Spain

CAC (Codex Alimentarius Commission) (2003), "Hazard Analysis and Critical Control Point (HACCP) System and Guidelines for its application", Codex Alimentarius Commission Food Hygiene Basic Texts (Revision 4). Available at: http://www.codexalimentarius.org

CAC/RCP (1969). General Principles of Food Hygiene, CAC/RCP1-1999, Codex Alimentarius, Revised 2003

Carugi, C. (2016). "Experiences with systematic triangulation at the global environment facility", Evaluation and Program Planning, 55(1), 55-66, available at:

http://dx.doi.org/10.1016/j.evalprogplan.2015.12.001

CBRI (Campden BRI) (2015). HACCP: a practical guide (5 th Edition) Guideline no.42 Editor R. Gaze ISBN 9780907503828 Chipping Campden UK

CBRI (Campden BRI) (2009). HACCP: a practical guide (4th Edition) Guideline no.42 Editor R. Gaze ISBN 9780907503521 
1018

1019

1020

1021

1022

1023

1024

1025

1026

1027

1028

1029

1030

1031

1032

1033

1034

1035

1036

1037

1038

1039

1040

1041

1042

1043

1044

1045

1046

1047

1048

1049

1050

1051

1052

1053

1054

1055

1056

1057

1058

1059

1060

1061

1062

1063

1064

1065

1066

1067

1068

1069

1070

1071

Chhikara, N., Jaglan, S., Sindhu, N., Veera, A.V.M., Charan, S., \& Panghal, A. (2018). Importance of Traceability in Food Supply Chain for Brand Protection and Food Safety Systems Implementation. Annals of Biology, 34(2), 111-118.

Codex (1993). Codex Alimentarius Commission. 1993. Recommended international code of practice. General principles of food hygiene. Annex to CAC/RCP 1-1969. Rome. Italy

Codex (1997). Codex Alimentarius Commission. Hazard Analysis and Critical Control Point (HACCP) System and Guidelines for its application. Annex to CAC/RCP 1-1969. Revision 3 Rome.

Italyhttp://www.fao.org/3/y1579e/y1579e03.htm

Codex, (2017). Joint FSO/WHO Food Standards Programme, Codex Committee on Food Hygiene, Report of the forty-ninth session of the Codex Committee on Food Hygiene, Chicago, Illinois, United States of America, 13 - 17 November 2017, p3, http://www.fao.org/fao-who-codexalimentarius/shproxy/en/?lnk=1\&url=https\%253A\%252F\%252Fworkspace.fao.org\%252Fsites\%252Fcodex\%252FMeetin gs\%252FCX-712-49\%252FReport\%252FREP18 FHe.pdf

Codex (2014). Joint FSO/WHO Food Standards Programme, Codex Committee on Food Hygiene, $46^{\text {th }}$ Session, Lima, Peru, 17-21 November 2014, Discussion paper on the need for a revision of the General Principles of Food Hygiene (CAC/RCP 1-1969_ and its HACCP Annex (Prepared by Finland with input from New Zealand and the United States of America), FH/46 CRD/2, http://www.fao.org/tempref/codex/Meetings/CCFH/ccfh46/CRDs/FH46 CRD02e.pdf

Codex (Joint FAO/WHO Food Standards Programme, Codex Alimentarius Commission) (2009). Hazard analysis and critical control point (HACCP) system and guidelines for its application. Food Hygiene Basic Texts, Fourth Edition. Joint FAO/WHO Food Standards Programme, Food and Agriculture Organization of the United Nations, Rome. http://www.fao.org/docrep/012/a1552e/a1552e00.htm

Coolen, H., \& Ozaki, R. (2004). Culture, Lifestyle and the Meaning of a Dwelling. In: International Conference on Adequate and Affordable Housing for All. Research, Policy and Practice, 24-27. International Conference Toronto, June 24-27, 2004

Czinkota, M., Kaufmann, H.R., \& Basile, G., (2014). The relationship between legitimacy, reputation, sustainability and branding for companies and their supply chains, Industrial Marketing Management, 43(1), 91-101. doi.org/10.1016/j.indmarman.2013.10.005

De Boeck, E., Jacxsens, L., Vanoverberghe, P., \& Vlerick, P. (2018). Method triangulation to assess different aspects of food safety culture in food service operations. Food Research International. 116, 1103-1112 doi.org/10.1016/i.foodres.2018.09.053

De Boeck, E., Jacxsens, L., Mortier, A. V., \& Vlerick, P. (2018). Quantitative study of food safety climate in Belgian food processing companies in view of their organizational characteristics. Food Control, 88, 1527. DOI: 10.1016/j.foodcont.2017.12.037

De Boeck, E., Jacxsens, L., Bollaerts, M., \& Vlerick, P., (2015). Food safety climate in food processing organisations. Development and validation of a self-assessment tool. Trends in Food Science and Technology, 46, 242-251. DOI: 10.1016/j.tifs.2015.09.006

Delmas, M. \& Toffel, M. W. (2004). Stakeholders and environmental management practices: an institutional framework. Business strategy and the Environment, 13(4), 209-222.

https://doi.org/10.1002/bse.409

Deming W.E. (1986). Out of the crisis. Cambridge, MA: Massachusetts Institute of Technology Center for Advanced Engineering Study xiii, 1991, 507 Cambridge USA 
1072

1073

1074

1075

1076

1077

1078

1079

1080

1081

1082

1083

1084

1085

1086

1087

1088

1089

1090

1091

1092

1093

1094

1095

1096

1097

1098

1099

1100

1101

1102

1103

1104

1105

1106

1107

1108

1109

1110

1111

1112

1113

1114

1115

1116

1117

1118

1119

1120

1121

1122
Demortain, D., (2007). Standardising through concepts: scientific experts and the international development of the HACCP Food Safety Standard. Centre for Analysis of Risk and Regulation, London School of Economics and Political Science. London

DiMaggio, P.J. \& W.W. Powell (1983). The Iron Cage Revisited: Institutional Isomorphism and Collective Rationality in Organizational Fields. American Sociological Review, 48(2): 147-160.

European Commission (EC) (1997). European Commission Scientific Committee for Food, Brussels European Commission 1997 (93/43/EEC; expressed on 13 June 1997).

EC European Commission (2004). Regulation (EC) No 852/2004 of the European parliament and the Council of 29 April 2004 on the hygiene of foodstuffs, available at:

http://eurlex.europa.eu/LexUriServ/LexUriServ.do?uri=OJ:L:2004:226:0003:0021:EN:PDF Unofficial consolidated version available at http://eurlex.europa.eu/LexUriServ/LexUriServ.do?uri=CONSLEG:2004R0852:20090420:EN:PDF (accessed 29 December 2017)

Emond, B., \& Taylor, J.Z. (2018). The importance of measuring food safety and quality culture: results from a global training survey. Worldwide Hospitality and Tourism Themes, 10(3), 369-375. https://doi.org/10.1108/WHATT-02-2018-0012

Escriche, I., Doménech, E., \& Baert, K. (2006). Design and implementation of an HACCP systemImplementation of prerequisites. In: Luning, P.A., Devlieghere, F., Verhé, R. (eds.). Safety in Agri-food chains. Wageningen Academic Publishers, Wageningen. The Netherlands, pp314-330.

Esfahbodi, A., Zhang, Y., Watson, G., \& Zhang, T. (2017). Governance pressures and performance outcomes of sustainable supply chain management-an empirical analysis of UK manufacturing industry. Journal of Cleaner Production, 155, 66-78. https://doi.org/10.1016/j.jclepro.2016.07.098

FAO. (Food and Agriculture Organization of the United Nations) (no date a). Procedures for the Elaboration of Codex Standards and Related Texts, http://www.fao.org/3/Y2200E/y2200e04.htm

FAO. (Food and Agriculture Organization of the United Nations) (no date b). The step procedure for elaborating Codex Standards, http://www.fao.org/fileadmin/user upload/codexalimentarius/photoarchive/Infographics/UnderstandingC Process En 160706.pdf

FAO. (Food and Agriculture Organization of the United Nations) (2003). Assuring food safety and quality: Guidelines for strengthening national control systems. FAO Food and Nutrition Paper 76. ISBN 02544725.

FAO (Food and Agriculture Organization of the United Nations) (1994). Grain storage techniques: Evolution and trends in developing countries. Eds D.L Proctor. FAO Agricultural Services Bulletin No. 109. Rome 1994

FDA (US Food and Drug Administration) (2017a). 2017 Recalls, Market Withdrawals \& Safety Alerts Available at: https://www.fda.gov/Safety/Recalls/ArchiveRecalls/2017/default.htm (accessed 29 December 2017)

FDA (US Food and Drug Administration) (2017b). Title 21-Food and Drugs Chapter 1 - Food and Drugs Administration Department of Health and Human Services Subchapter B- Food for Human Consumption. Part 121. Mitigation Strategies to Protect Food against Intentional Adulteration. Available at: https://www.accessdata.fda.gov/scripts/cdrh/cfdocs/cfCFR/CFRSearch.cfm?CFRPart=121\&showFR=1 
1123

1124

1125

1126

1127

1128

1129

1130

1131

1132

1133

1134

1135

1136

1137

1138

1139

1140

1141

1142

1143

1144

1145

1146

1147

1148

1149

1150

1151

1152

1153

1154

1155

1156

1157

1158

1159

1160

1161

1162

1163

1164

1165

1166

1167

1168

1169

1170

1171

1172

1173

1174

1175

Ferrando, M., Bagnasco, D., Varricchi, G., Bernardi, S., Bragantini, A., Passalacqua, G., \& Canonica, G. W. (2017). Personalized medicine in allergy. Allergy, asthma \& immunology research, 9(1), 1524. https://doi.org/10.4168/aair.2017.9.1.15

Food Safety System Certification 22000 (FSSC 22000) http://www.fssc22000.com/documents/home (accessed March 2019)

Flores-Miyamoto, A., Reij, M.W., \& Velthuis, A.G.J., (2014). Do farm audits improve milk quality?. Journal of dairy science, 97(1), 1-9. https://doi.org/10.3168/jds.2012-6228

FSA (Food Standards Agency) (2017). Safer Food Better Business, Available at: https://www.food.gov.uk/business-industry/sfbb (accessed 29 December 2017).

Fulponi, L., (2006). Private voluntary standards in the food system: The perspective of major food retailers in OECD countries. Food policy, 31(1),1-13. DOI: 10.1016/j.foodpol.2005.06.006.

Galperin, B. L., \& Burke, R. J. (2006). Uncovering the relationship between workaholism and workplace destructive and constructive deviance: An exploratory study. The International Journal of Human Resource Management, 17(2), 331-347. https://doi.org/10.1080/09585190500404853

Galstyan, S.H., \& Harutyunyan, T.L., (2016). Barriers and facilitators of HACCP adoption in the Armenian dairy industry. British Food Journal, 118(11), 2676-2691. https://doi.org/10.1108/BFJ-02-2016-0057

GFSI (2013). The Global Food Safety Initiative GFSI Guidance Document. Version 6.3. October 2013

Ghaffarian, V. (2011). The new stream of socio-technical approach and main stream information systems research. Procedia Computer Science, 3, 1499-1511 https://doi.org/10.1016/i.procs.2011.01.039

Gimenez, C., Sierra V., \& Rodan J. (2012), Sustainable operations: their impact on the triple bottom Line, International Journal of Production 140(1), 149-159. https://doi.org/10.1016/j.ijpe.2012.01.035

GLOBALG.A.P. https://www.globalgap.org/ (accessed March 2019)

Griffith, C. (2014). Developing and Maintaining a Positive Food Safety Culture. $1^{\text {st }}$ Edition. Highfield Publications.

Griffith, C.J., Livesey K.M., \& Clayton, D.A., (2010). Food safety culture: the evolution of an emerging risk factor? British Food Journal, 112(4), 426-438. https://doi.org/10.1108/00070701011034439

Henson, S. \& Humphrey, J. (2010). Understanding the complexities of private standards in global agrifood chains as they impact developing countries. Journal of Development Studies, 46(9), 1628-1646.

DOI: $10.1080 / 00220381003706494$.

Henson, S., \& Reardon, T. (2005). Private agri-food standards: Implications for food policy and the agrifood system. Food Policy, 30, 241-253._DOI: 10.1016/j.foodpol.2005.05.002

Herath, D. \& Henson, S., (2010). Barriers to HACCP implementation: evidence from the food processing sector in Ontario, Canada. Agribusiness, 26(2), 265-279. DOI: 10.1002/agr.20245

Herath, D., Hassan, Z., \& Henson, S. (2007). Adoption of food safety and quality controls do firm characteristics matter? Evidence from the Canadian food processing sector. Canadian Journal of Agricultural economics-revue Canadienne D'Agroeconomie, 55(3), 299-314. DOI: 10.1111/j.17447976.2007.00093.x

Herzfeld, T., Drescher, L., \& Grebitus, C. (2011). Cross-national adoption of private food quality standards. Food Policy, 36, 401-411. DOI: 10.1016/j.foodpol.2011.03.006 
1176

1177

1178

1179

1180

1181

1182

1183

1184

1185

1186

1187

1188

1189

1190

1191

1192

1193

1194

1195

1196

1197

1198

1199

1200

1201

1202

1203

1204

1205

1206

1207

1208

1209

1210

1211

1212

1213

1214

1215

1216

1217

1218

1219

1220

1221

1222

1223

1224

1225

1226

1227

Hofstede, G. (1997). Cultures and Organizations: Software of the Mind. New York, NY: McGraw-Hill.

Hofstede, G. (2001). Culture's consequences: Comparing values, behaviors, institutions, and organizations across nations, 2nd. Ed Sage Thousand Oaks, California

Höijer, B. (2011). Social representations theory. Nordicom review, 32(2), 3.

Hood, C. \& Rothstein, H. (2001). Risk regulation under pressure: problem solving or blame shifting? London: LSE Research Articles Online. Available at: http://eprints.Ise.ac.uk/archive/00000335/

International Featured Standards (IFS) (2018). Global Safety and Quality Standards, Available at: https://www.ifs-certification.com/index.php/en/standards, (accessed 18 October 2018).

International Commission on Microbiological Specifications for Foods (ICMSF) (1988). Application of the hazard analysis critical control point (HACCP) system to ensure microbiological safety and quality. Microorganisms in Foods 4. Blackwell Scientific, Oxford

International Organization for Standardization (ISO), (2005), Food Safety Management Systems Requirements for any organization in the food chain. BS EN ISO 22000:2005.

International Organization for Standardization (ISO), (2015), ISO 9000, 2015. Quality management systems - fundamentals and vocabulary. ISO London, Available at:

https://www.iso.org/obp/ui/\#iso:std:iso:9000:ed-4:v1:en (accessed 18 October 2018)

International Organization for Standardization (ISO), (2018), Food Safety Management Systems Requirements for any organization in the food chain. BS EN ISO 22000:2018.

Jacxsens, L., Kirezieva, K., Luning, P.A., Ingelrham, J., Diricks, H., \& Uyttendaele, M. (2015). Measuring Microbial Food Safety Output and Comparing Self-Checking Systems of Food Business Operators in Belgium. Food Control, 49, 59-69. DOI: 10.1016/j.foodcont.2013.09.004

Jacxsens, L., Uyttendaele, M., \& De Meulenaer, B., (2016). Challenges in risk assessment: quantitative risk assessment, Procedia Food Science, 6, 23-30. doi.org/10.1016/i.profoo.2016.02.004

Jespersen, L., \& Huffman, R. (2014). Building food safety into the company culture: a look at Maple Leaf Foods. Perspectives in Public Health, 134(4), 200-205. DOI: 10.1177/1757913914532620

Jespersen, L., Griffiths, M., Maclaurin, T., Chapman, B., \& Wallace, C.A. (2016), Measurement of food safety culture using survey and maturity profiling tools, Food Control, 66(1), 174-182. DOI:

10.1016/j.foodcont.2016.01.030

Jespersen, L., Griffiths, M., \& Wallace, C.A., (2017). Comparative analysis of existing food safety culture evaluation systems. Food Control, 79, 371-379. DOI: 10.1016/j.foodcont.2017.03.037

Jespersen, L., \& Wallace, C. A. (2017). Triangulation and the importance of establishing valid methods for food safety culture evaluation. Food Research International, 100, 244-253. DOI:

10.1016/j.foodres.2017.07.009

Jespersen, L., Butts, J., Holler, G., Taylor, J., Harlan, D., Griffiths, M., \& Wallace, C.A., (2019). The impact of maturing food safety culture and a pathway to economic gain, Food Control, 98, 367-379. doi.org/10.1016/i.foodcont.2018.11.041 
1228

1229

1230

1231

1232

1233

1234

1235

1236

1237

1238

1239

1240

1241

1242

1243

1244

1245

1246

1247

1248

1249

1250

1251

1252

1253

1254

1255

1256

1257

1258

1259

1260

1261

1262

1263

1264

1265

1266

1267

1268

1269

1270

1271

1272

1273

1274

1275

1276

1277

1278

1279

1280

1281

1282
Kane, K., Taylor, J. Z., \& Teare, R. (2018). Reflections on the theme issue outcomes: can the culture of safety and quality in organizations be measured and changed?. Worldwide Hospitality and Tourism Themes, 10(3), 391-396 https://doi.org/10.1108/WHATT-02-2018-0016

Kates, R.W. \& Kasperson, J.X. (1983). Comparative risk analysis of technological hazards: a review. Proceedings of the National Academy of Sciences. 80, 7027-7038. https://doi.org/10.1073/pnas.80.22.7027

Kerstholt, J. (1994). The effect of time pressure on decision-making behaviour in a dynamic task environment. Acta Psychologica, 86(1), 89-104. https://doi.org/10.1016/0001-6918(94)90013-2

Khatib, T.M., (1996), Organizational culture, subcultures, and organizational commitment, Retrospective Theses and Dissertations. Paper 11540.

Kirezieva, K., Nanyunja, J., Jacxsens, L., van der Vorst, J.G.A.J., Uyttendaele, M., \& Luning, P.A. (2013). Context factors affecting design and operation of Food Safety Management Systems in the fresh produce chain. Trends in Food Science \& Technology, 23, 108-127. DOI: 10.1016/j.tifs.2013.06.001

Kirezieva, K., Luning, P.A., Jacxsens, L. M., Uyttendaele, M., Allende, A., Johannessen, G.S., \& Tondo, E.C. (2015a). Factors affecting the status of food safety management systems in the global fresh produce chain. Food Control, 52, 85-97. DOI: 10.1016/j.foodcont.2014.12.030

Kirezieva, K., Jacxsens, L., Hagelaar, G. J.L.F., van Boekel, M.A.J.S., Uyttendaele, M., \& Luning, P.A. (2015b). Exploring the influence of context on food safety management: Case studies of leafy greens production in Europe. Food Policy, 51, 158-170. DOI: 10.1016/j.foodpol.2015.01.005

Kirezieva K., \& Luning, P.A. (2017). The influence of context on food safety governance: Bridging the gap between policy and quality management. In P. Verbruggen, P. \& H. Havinga, H. Hybridization of Food Governance: Trends, Types and Results. (pp. 156-179).Edward Elgar Publishing. London

Kirkpatrick, B. D., \& Tribble, D. R. (2011). Update on human Campylobacter jejuni infections. Current opinion in gastroenterology, 27(1), 1-7.

Kleboth, J., \& Strasser, A. (2013). Food Safety- and Quality Management Schemes - Towards a Harmonized Concept Concerning FSSC 22000, BRC Global Standard for Food Safety 6 and International Featured Standard for Food 6. University of Natural Resources and Life Sciences, Vienna.

Kleboth, J.A., Luning, P.A., \& Fogliano, V., (2016). Risk-based integrity audits in the food chain-a framework for complex systems. Trends in Food Science \& Technology, 56, 167-174. DOI:

10.1016/j.tifs.2016.07.010

Kotsanopoulos, K.V. \& Arvanitoyannis, I.S. (2017). The Role of Auditing, Food Safety, and Food Quality Standards in the Food Industry: A Review. Comprehensive Reviews in Food Science and Food Safety, 16(5), 760-775. DOI: 10.1111/1541-4337.12293

Kussaga, J. B, Luning, P.A., Tiisekwa, B.P.M., \& Jacxsens, L. (2015). Current performance of Food Safety Management Systems of Dairy Processing Companies in Tanzania. International Journal of Dairy Technology, 68(2), 227-252. DOI: 10.1002/jsfa.6575

La Chance, P. A. (2006). Oral history transcript. NASA Johnson Space Centre Oral History Project, Interview by Jennifer Ross-Nazzal, Houston, Texas and New Brunswick, New Jersey, 4 May 2006 Available at: http://www.jsc.nasa.gov/history/oral_histories/participants.htm (accessed 28 December 2017).

Läikkö-Roto, T. \& Nevas, M., (2014). Auditing local official food control: perceptions of auditors and auditees. Food control, 37, 135-140. https://doi.org/10.1016/.foodcont.2013.09.021 
1283

1284

1285

1286

1287

1288

1289

1290

1291

1292

1293

1294

1295

1296

1297

1298

1299

1300

1301

1302

1303

1304

1305

1306

1307

1308

1309

1310

1311

1312

1313

1314

1315

1316

1317

1318

1319

1320

1321

1322

1323

1324

1325

1326

1327

1328

1329

1330

1331

1332

1333

1334

1335

1336
Latouche, K. \& Chevassus-Lozza, E. (2015). Retailer Supply Chain and Market Access: Evidence From French Agri-food Firms Certified with Private Standards. World Economy, 38(8), 1312-1334. DOI: 10.1111/twec.12191

Leat, P. \& Revoredo-Giha, C. (2013). Risk and resilience in agri-food supply chains: the case of the ASDA PorkLink supply chain in Scotland, Supply Chain Management: An International Journal, 18(2), 219-213. https://doi.org/10.1108/13598541311318845

Leeuw, F. L. (2011). On the effects, lack of effects and perverse effects of performance audit. In J. Lonsdale, P. Wilkins, \& T. Ling (Eds.), Performance auditing (pp. 231-247).

Leiserowitz, A.A., (2003). Global warming in the American mind: The roles of affect, imagery, and worldviews in risk perception, policy preferences and behavior (Doctoral dissertation, University of Oregon).

Lowe, J.P \& Taylor, J.Z, (2013). Barriers to HACCP amongst UK farmers and growers: an in-depth qualitative study. British Food Journal, 115(2), 262-278. https://doi.org/10.1108/00070701311302230

Luning, P. A., Marcelis, W. J., \& Jongen, W. M. (2002). Food quality management: a techno-managerial approach (1 ${ }^{\text {st }}$ edition). Wageningen, Wageningen Press.

Luning, P.A. \& Marcelis, W.J., (2006). A techno-managerial approach in food quality management research. Trends in Food Science \& Technology, 17(7), 378-385. DOI: 10.1016/j.tifs.2006.01.012

Luning, P.A. \& Marcelis, W.J., (2007). A conceptual model of food quality management functions based on a techno-managerial approach. Trends in Food Science \& Technology, 18(3), 159-166. DOI: 10.1016/j.tifs.2006.10.021

Luning, P.A., Bango, L., Kussaga, J., Rovira, J., \& Marcelis, W.J. (2008). Comprehensive analysis and differentiated assessment of food safety control systems: a diagnostic instrument. Trends in Food Science \& Technology, 19, 522-534. DOI: 10.1016/j.tifs.2008.03.005

Luning, P.A., \& Marcelis, W.J. (2009). Food Quality Management: technological and managerial principles and practices ( $2^{\text {nd }}$ edition). Wageningen, Wageningen Academic Publishers.

Luning, P.A., Marcelis, W.J., Rovira, J., Van der Spiegel, M., Uyttendaele, M., \& Jacxsens, L. (2009). Systematic assessment of core assurance activities in company specific food safety management systems. Trends in Food Science \& Technology, 20, 300-312. DOI: 10.1016/j.tifs.2009.03.003

Luning, P.A., Marcelis, W. J., van Boekel, M.A.J.S., Rovira, J., Uyttendaele, M., \& Jacxsens, L. (2011a). A tool to diagnose context riskiness in view of food safety activities and microbiological safety output. Trends in food Science \& technology 22(1), S67-S79. DOI: 10.1016/j.tifs.2010.09.009

Luning, P. A., Jacxsens, L., Rovira, J., Oses, S. M., Uyttendaele, M., \& Marcelis, W. J. (2011b). A concurrent diagnosis of microbiological food safety output and food safety management system performance: cases from meat processing industries. Food Control, 22, 555-565. DOI: 10.1016/j.foodcont.2010.10.003

Luning, P.A, Kirezieva, K., Hagelaar, G. Rovira, J. Uyttendaele, M., \& Jacxsens, L. (2015). Performance assessment of food safety management systems in animal-based food companies in view of their context characteristics: a European study. Food Control, 49, 11-22. DOI: 10.1016/j.foodcont.2013.09.009

Manning, L., Baines, R.N., \& Chadd, S.A., (2006). Quality assurance models in the food supply chain. British Food Journal, 108(2), 91-104 https://doi.org/10.1108/00070700610644915 
1337

1338

1339

1340

1341

1342

1343

1344

1345

1346

1347

1348

1349

1350

1351

1352

1353

1354

1355

1356

1357

1358

1359

1360

1361

1362

1363

1364

1365

1366

1367

1368

1369

1370

1371

1372

1373

1374

1375

1376

1377

1378

1379

1380

1381

1382

1383

1384

1385

1386

1387

1388

1389

1390

1391

1392

Manning, L. (2013). Development of a food safety verification risk model. British Food Journal, 115(4), 575-589 https://doi.org/10.1108/00070701311317856

Manning, L., \& Soon, J.M., (2013). Mechanisms for assessing food safety risk, British Food Journal, 115(3), 460-484 https://doi.org/10.1108/00070701311314255

Manning, L., \& Soon, J.M, (2014). Developing systems to control food adulteration, Food Policy, 49(1), 23-32 https://doi.org/10.1016/j.foodpol.2014.06.005

Manning, L., \& Soon, J.M., (2016a). Food safety, food fraud and food defence: a fast evolving literature. Journal of Food Science, 81(4) R823-R834 https://doi.org/10.1111/1750-3841.13256

Manning, L., \& Soon, J.M., (2016b). Building strategic resilience in the food supply chain. British Food Journal, 116(6), 1477-1493 https://doi.org/10.1108/BFJ-10-2015-0350

Manning, L., Wallace, C., \& Soon, J.M. (2016). Foodborne Disease Outbreaks in Complex Manufacturing Establishments in Soon, J.M., Manning, L. \& Wallace, C. (2016), Eds. Foodborne Diseases: Case studies of outbreaks in the agri-food industries. CRC Press. Taylor \& Francis

Manning, L. (2017a). Categorizing food related illness: have we got it right? Critical Reviews in Food Science and Nutrition, 57(9), 1938-1949 https://doi.org/10.1080/10408398.2015.1038776

Manning, L. (2017b). The interaction between organizational sub-cultures and its influence on food safety management. Journal of Marketing Channels, 24(3-4), 1-10 https://doi.org/10.1080/1046669X.2017.1393235

Manning, L., \& Soon, J.M., (2017). An alternative allergen risk management approach, Critical Reviews in Food Science and Nutrition. 57(18), 3873-3886 https://doi.org/10.1080/10408398.2016.1185085

Manning, L. Soon. J.M., de Aguiar, L.K., Eastham, J.F., \& Higashi, S.Y. (2017). Pressure: driving illicit behaviour in the food supply chain. 12th Research Workshop on Institutions and Organisations (12th RWIO) Brazil 10-11 July 2017

Manning, L. (2018a). The value of food safety culture to the hospitality industry. World Hospitality and Tourism Themes 10(3), 284-296 https://doi.org/10.1108/WHATT-02-2018-0008

Manning L. (2018b). Triangulation: effective verification of food safety and quality management systems and associated organisational culture. World Hospitality and Tourism Themes 10(3), 297-312 https://doi.org/10.1108/WHATT-02-2018-0009

Manning, L. (2018c). Systems for sustainability and transparency of food supply chains, in Charis ed. Sustainable Food Systems From Agriculture to Industry, Elsevier. London

Manning, L. \& Luning, P. A. (2018). Chapter 16: Determining farm derived food safety risk in Food safety for the $21^{\text {st }}$ Century: Managing HACCP and Food Safety through the Global Chain, Wallace et al. (pp.315-330) Wiley Blackwell. Oxford. UK

Manning L. (2019), Food defence: refining the taxonomy of food defence threats, Trends in Food Science and Technology, 85, 107-115, https://doi.org/10.1016/j.tifs.2019.01.008

Martz, W., (2010). Validating an evaluation checklist using a mixed method design. Evaluation and program planning, 33(3), 215-222. https://doi.org/10.1016/j.evalprogplan.2009.10.005

Masuda, J.R. \& Garvin, T., (2006). Place, culture, and the social amplification of risk. Risk analysis, 26(2), 437-454. https://doi.org/10.1111/j.1539-6924.2006.00749.x 
1393

1394

1395

1396

1397

1398

1399

1400

1401

1402

1403

1404

1405

1406

1407

1408

1409

1410

1411

1412

1413

1414

1415

1416

1417

1418

1419

1420

1421

1422

1423

1424

1425

1426

1427

1428

1429

1430

1431

1432

1433

1434

1435

1436

1437

1438

1439

1440

1441

1442

1443

1444

Mayes, T. (1992). Simple users' guide to the hazard analysis critical control point concept for the control of food microbiological safety. Food Control, 3(1), 14-19. https://doi.org/10.1016/0956-7135(92)90167-9

Mensah, L. D., \& Julien, D. (2011). Implementation of food safety management systems in the UK. Food Control, 22(8), 1216-1225 https://doi.org/10.1016/j.foodcont.2011.01.021

Meuwissen, M. P. M., Velthuis, A. G. J., Hogeveen, H., \& Huirne, R. B. M. (2003). Technical and economic considerations about traceability and certification in livestock production chains. In A. G. J. Velthuis, L.J. Unnevehr, H., Hogeveen, \& R.B. Huirne (eds.): New approaches to food safety economics, (pp. 41-54) Wageningen, Wageningen Academic Publishers.

Monaghan, J.M., Augustin, J.C., Bassett, J., Betts, R., Pourkomailian, B., \& Zwietering, M.H., (2017). Risk assessment or assessment of risk? Developing an evidence-based approach for primary producers of leafy vegetables to assess and manage microbial risks. Journal of Food Protection, 80(5), 725-733. https://doi.org/10.4315/0362-028X.JFP-16-237

Mortimore, S.E. \& Wallace, C.A., (1994), HACCP - a practical approach, Chapman \& Hall, London. UK.

Mortimore, S.E. \& Wallace, C.A., (1998), HACCP - a practical approach $2^{\text {nd }}$ Ed., Aspen Publishers Inc., Gaithersburg, USA

Mortimore, S.E \& Wallace, C.A. (2013), HACCP A Practical Approach. Third Edition. Springer. New York, USA ISBN 9781461450276

Mortimore, S.E. \& Wallace, C.A., (2015). HACCP: A food industry briefing. John Wiley \& Sons. London

Nanyunja, J. Jacxsens, L. Kirezieva, K., Kaaya, A.N. Uyttendaele, M., \& Luning, P.A. (2016). Shift in performance of food safety management systems in supply chains: case of green bean chain in Kenya versus hot pepper chain in Uganda. Journal of the Science of Food and Agriculture, 96, 3380-3392. DOI: $10.1002 / j s f a .7518$

National Advisory Committee on Microbiological Criteria for Foods (NACMCF), (1992). Hazard Analysis and Critical Control Point System (adopted 20 March 1992), International Journal of Food Microbiology, 16, 1-23.

National Advisory Committee on Microbiological Criteria for Foods (NACMCF), (1997). Hazard Analysis and Critical Control Point System (adopted 14 August 1997),

Nayak, R., \& Waterson, P. (2015). The challenges of assessing food safety culture. The Ergonomist, 540, 12-13.

Nayak, R., \& Waterson, P., (2016). 'When Food Kills': A socio-technical systems analysis of the UK Pennington 1996 and 2005 E. coli $O 157$ Outbreak reports. Safety Science, 86, 36-47. DOI:

10.1016/j.ssci.2016.02.007

Nayak, R., \& Waterson, P., (2017). The Assessment of Food Safety Culture: An investigation of current challenges, barriers and future opportunities within the food industry. Food Control, 73, pp.1114-1123.

DOI: 10.1016/j.foodcont.2016.10.061

Nayak, R., \& Taylor, J. Z. (2018). Food safety culture-the food inspectors' perspective. Worldwide Hospitality and Tourism Themes, 10(3), 376-381 DOI: 10.1108/WHATT-02-2018-0013 
1445

1446

1447

1448

1449

1450

1451

1452

1453

1454

1455

1456

1457

1458

1459

1460

1461

1462

1463

1464

1465

1466

1467

1468

1469

1470

1471

1472

1473

1474

1475

1476

1477

1478

1479

1480

1481

1482

1483

1484

1485

1486

1487

1488

1489

1490

1491

1492

1493

1494

1495

1496

1497

1498

NRC (National Research Council) (1985). An Evaluation of the Role of Microbiological Criteria for Foods and Food Ingredients. Editors (US) Subcommittee on Microbiological Criteria. Washington (DC): National Academies Press (US); 1985.

Nyarugwe, P.A., Linnemann, A., Hofstede, G, Fogliano, V. \& Luning, P.A. (2016). Determinants for conducting food safety culture research. Trends in Food Science \& Technology, 56, 77-87. DOI: 10.1016/j.tifs.2016.07:015

Nyarugwe, S.P., Linnemann, A., Nyanga, L.K., Fogliano, V., \& Luning, P.A., (2018). Food safety culture assessment using a comprehensive mixed-methods approach: A comparative study in dairy processing organisations in an emerging economy. Food Control, 84, 186-196. DOI: 10.1016/j.foodcont.2017.07.038

Nguyen, T., Wilcock, A., \& Aung, M. (2004), Food safety and quality systems in Canada: an exploratory study. International Journal of Quality \& Reliability Management, 21(6), 655-671. https://doi.org/10.1108/02656710410542052

Official Journal of the European Union (2004). Regulation (EC) No 852/2004 of the European Parliament and the council of $29^{\text {th }}$ April 2004 on the hygiene of foods stuffs

Othman, R., Ahmad, Z.A., \& Zailani, S., (2009). The effect of institutional pressures in the Malaysian Halal Food Industry, International Business Management, 3(4), 80-84

Panghal, A., Chhikara, N., Sindhu, N., \& Jaglan, S. (2018). Role of Food Safety Management Systems in safe food production: A review. Journal of food safety, 38(4), e12464.

Panisello, P. J., \& Quantick, P. C. (2001). Technical barriers to hazard analysis critical control point (HACCP). Food Control, 12(3), 165-173. https://doi.org/10.1016/S0956-7135(00)00035-9

Peters, E.M., Burraston, B, \& Mertz, C.K., (2004). An emotion-based model of risk perception and stigma susceptibility: Cognitive appraisals of emotion, affective reactivity, worldviews, and risk perceptions in the generation of technological stigma. Risk analysis, 24(5), 1349-1367. https://doi.org/10.1111/j.02724332.2004.00531.x

Petersen, K. S. (2009). Third-Party Audit Programs for the Fresh-Produce Industry. Microbial Safety of Fresh Produce, 321-329.

Powell, D.A., Jacob, C.J., \& Chapman, B.J. (2011). Enhancing food safety culture to reduce rates of foodborne illness, Food Control, 22, 817-822 https://doi.org/10.1016/j.foodcont.2010.12.009

RASFF (2017). Available at: https://ec.europa.eu/food/safety/rasff/portal en (Accessed 29 December 2017)

Rogers, E. M. (2003). Diffusion of Innovations, Free Press, Fifth Edition, New York, 2003

Rapoport, A., (1988). Levels of meaning in the built environment, In: F. Poyatos (ed.), Cross-cultural perspectives in nonverbal communication, C.J. Hogrefe, Toronto, pp. 317-336.

Ross-Nazzal, J. (2007). From farm to fork: How space food standards impacted the food industry and changed food safety standards. In S. J. Dick, \& R. D. Launius (Eds.), Societal impact of spaceflight. Washington: National aeronautics and Space administration, Office of External Relations-History Division (NaSa Sp-2007- 4801). http://history.nasa.gov/sp4801-part1.pdf (accessed 28 December 2017)

Rothstein, H. Huber, M., \& Gaskell, G. (2006). A Theory of Risk Colonisation: The spiraling regulatory logics of societal and institutional risk, Economy and Society, 35(1), 91-112

https://doi.org/10.1080/03085140500465865 
1499

1500

1501

1502

1503

1504

1505

1506

1507

1508

1509

1510

1511

1512

1513

1514

1515

1516

1517

1518

1519

1520

1521

1522

1523

1524

1525

1526

1527

1528

1529

1530

1531

1532

1533

1534

1535

1536

1537

1538

1539

1540

1541

1542

1543

1544

1545

1546

1547

1548

1549

1550

1551

1552
Safe Quality Food Institute Standards (2018) Available at: https://www.safi.com/standards/ [Accessed $27^{\text {th }}$ August 2018]

Sarkis, J., Zhu, Q., \& Lai, K. H. (2011). An organizational theoretic review of green supply chain management literature. International Journal of Production Economics, 130(1), 1-15.

https://doi.org/10.1016/i.ijpe.2010.11.010

Schaarschmidt, S. (2016). Public and private standards for dried culinary herbs and spices - Part I: Standards defining the physical and chemical product quality and safety. Food Control, 79, 339-349. DOI: 10.1016/j.foodcont.2016.06.004

Schein, E.H. (1985). Organizational culture and leadership. San Francisco, CA: Jossey-Bass.

Schulze, H., Albersmeier, F., Gawron, J.C., Spiller, A., \& Theuvsen, L. (2008). Heterogeneity in the Evaluation of Quality Assurance Systems: The International Food Standard (IFS) in European Agribusiness. International food and Agribusiness Management Review, 11(3), 99-138.

Slovic, P. (1999). Trust, emotion, sex, politics, and science: Surveying the risk-assessment battlefield. Risk analysis, 19(4), 689-701.

Slovic, P. (2002). The perception of risk. Earthscan Publishers Ltd.

Sonntag, W., Theuvsen, L., Kersting, V., \& Otter, V. (2016). Have industrialised countries shut the door and left the key inside? Rethinking the role of private standards in the International fruit trade. International Food and Agribusiness Management Review, 19(2), 151- 170.

Soon, J.M., Manning, L., \& Wallace, C. (2016). Eds. Foodborne Diseases: Case studies of outbreaks in the agri-food industries. CRC Press. Taylor \& Francis. London

Spadoni, R. Lombardi, P., \& Canavari, M. (2013). Private food standard certification: analysis of BRC standard in Italian agri-food. British Food Journal, 116(1), 142-164. DOI: 10.1108/BFJ-08-2012-0201

Sperber, W.H. (2001). Hazard identification: from a quantitative to a qualitative approach. Food Control, 12(4), 223-228. https://doi.org/10.1016/S0956-7135(00)00044-X

Spink J., \& Moyer DC. (2011). Defining the public health threat of food fraud. Journal of Food Science, 769,157-63. https://doi.org/10.1111/j.1750-3841.2011.02417.x

Spreitzer, G.M. \& Sonenshein, S. (2003). "Positive deviance and extraordinary organizing." In Cameron, K.S., Dutton, J.E., and Quinn, R.E. (Eds.) Positive Organizational Scholarship: Foundations of a New Discipline. San Francisco: Berrett-Koehler.

Sprenger, R.A (2014). Hygiene for Management $17^{\text {th }}$ Edition. ISBN 978-1-909749-26-9 Highfield Publications, Yorkshire. UK

Taylor, J.Z, (2008). HACCP for the hospitality industry: a psychological model for success. International Journal of Contemporary Hospitality Management, 20(5), 508-523 https://doi.org/10.1108/09596110810881445

Taylor, E., \& Taylor, J.Z., (2004). Perceptions of "the bureaucratic nightmare" of HACCP: A case study. British Food Journal, 106(1), 65-72. https://doi.org/10.1108/00070700410515217

Taylor, J.Z. \& Rostron, K.I. (2018). The development of a safety and quality culture assessment tool from a longitudinal, mixed-method research journey. Worldwide Hospitality and Tourism Themes, 10(3), 313329. DOI:10.1108/WHATT-02-2018-0006 
1553

1554

1555

1556

1557

1558

1559

1560

1561

1562

1563

1564

1565

1566

1567

1568

1569

1570

1571

1572

1573

1574

1575

1576

1577

1578

1579

1580

1581

1582

1583

1584

1585

1586

1587

1588

1589

1590

1591

1592

1593

1594

1595

1596

1597

1598

1599

1600

1601

1602

1603

1604

1605

1606

1607
Taylor, J. Z., Caccamo, A., Daniel, D., \& Bulatovic-Schumer, R. (2018). Measuring and improving food safety culture in a 5 star hotel: a case study. Worldwide Hospitality and Tourism Themes, 10(3), 345357. https://doi.org/10.1108/WHATT-02-2018-0010

Ternhag, A., Törner, A., Svensson, Å., Ekdahl, K., \& Giesecke, J. (2008). Short-and long-term effects of bacterial gastrointestinal infections. Emerging infectious diseases, 14(1), 143.

doi: 10.3201/eid1401.070524

Theuvsen, L., \& Spiller, A. (2007). Perspectives of quality management in modern agribusiness. In:

Theuvsen, L. Spiller, A., Peupert, M. \& Jahn, G. (Eds.). Quality Management in Food Chains. pp. 13-19. Wageningen Academic Publishers. DOI: 10.3920/978-90-8686-605-2

Tey, Y.S., Rajendran, N., Brindal, M., Sidique, S.F.A., Shamsudin, M.N., Radam, A., \& Hadi, A.H.I.A. (2016). A review of an international sustainability standard (GLOBALG.A.P) and its local replica (MyGAP).Outlook on Agriculture, 45(1), 67-72. DOI: 10.5367/oa.2016.0230

Toropilová, J. \& Bystrický, P. (2015). Why HACCP might sometimes become weak or even fail. Procedia Food Science, 5, 296-299. https://doi.org/10.1016/j.profoo.2015.09.072

van Asseldonk, M.A.P.M. \& Velthuis, A.G.J., (2014). Risk-based audit selection of dairy farms. Journal of Dairy Science, 97(2), 592-597. https://doi.org/10.3168/ids.2013-6604

van der Linden, S., (2015). The social-psychological determinants of climate change risk perceptions: Towards a comprehensive model. Journal of Environmental Psychology, 41, 112-124. https://doi.org/10.1016/j.jenvp.2014.11.012

Van der Spiegel, M., Luning, P.A., De Boer, W.J., Ziggers, G.W. \& Jongen, W.M.F. (2005). How to improve food quality management in the bakery sector. NJAS-Wageningen Journal of Life Sciences, 53(2), 131-150. DOI: 10.1016/S1573-5214(05)80002-8

van Plaggenhoef, W. (2007). Integration and self regulation of quality management in Dutch agri-food supply chains: a cross-chain analysis of the poultry meat, the fruit and vegetable and the flower and potted plant chains. International Chains and Networks series (ISSN 1874-7663, 4.

Varzakas, T., \& Jukes, D. (1997). Globalisation of food quality standards: the impact in Greece. Food Policy, 22(6), 501-514. DOI: 10.1016/S0306-9192(98)00004-9

Vela, A.R. \& Fernández, J.M., (2003). Barriers for the developing and implementation of HACCP plans: results from a Spanish regional survey. Food Control, 14(5), 333-337. https://doi.org/10.1016/S09567135(02)00098-1

Verbruggen, P. (2016). Understanding the New Governance of Food Safety: Regulatory Enrolment as a Response to Change in Public and Private Power. Cambridge Cambridge Journal of International and Comparative Law, 5(3), 418-449. DOI:10.7574/cjicl.05.03.418

Verbruggen, P. \& Havinga, H. (eds.), (2017a). Hybridization of Food Governance: Trends, Types and Results. Edward Elgar Publishing.

Verbruggen, P \& Havinga, T. (2017b). Hybridization of food governance: An analytical framework. In: Verbruggen, P. and Havinga, T. ed. Hybridization of food governance: trends, types and results. Cheltenham: Edward Elgar Publishing. pp. 1-27.

Wallace, C.A. (2006). Safety in food processing. Food processing handbook, pp.351-372. 
1608

1609

1610

1611

1612

1613

1614

1615

1616

1617

1618

1619

1620

1621

1622

1623

1624

1625

1626

1627

1628

1629

1630

1631

1632

1633

1634

1635

1636

1637

1638

1639

1640

1641

1642

1643

1644

1645

1646

1647

1648

1649

1650

1651

1652

1653

1654

1655

1656

1657

1658

1659

1660

1661

1662

1663

Wallace, C.A. (2014), HACCP-based Food Safety Management Systems - Great in theory but can we make them work in practice, Perspectives in Public Health, 134(4), 188-190.

Wallace, C.A. \& Williams, A., (2001). Pre-requisites: a help or a hindrance to HACCP?. Food control, 12(4), 235-240. doi.org/10.1016/S0956-7135(00)00042-6

Wallace, C. A., Powell, S. C., \& Holyoak, L. (2005), Post-training assessment of HACCP Knowledge: its use as a predictor of effective HACCP development, implementation and maintenance in food manufacturing. British Food Journal, 107(10), 743-759. doi: 10.1108/00070700510623522

Wallace, C.A., Sperber, W.H., \& Mortimore, S.E., (2011). Food Safety for the $21^{\text {st }}$ Century: Managing HACCP and Food Safety Through the Global Supply Chain. Wiley Blackwell. Oxford London. ISBN 9781405189118

Wallace, C.A., Holyoak, L., Powell, S.C., \& Dykes, F.C., (2014). HACCP-the difficulty with hazard analysis. Food Control, 35(1), 233-240. doi.org/10.1016/j.foodcont.2013.07.012

Wallace, C.A., Holyoak, L., Powell, S.C., \& Dykes, F.C., (2012). Re-thinking the HACCP team: An investigation into HACCP team knowledge and decision-making for successful HACCP development. Food Research International, 47(2), 236-245. doi.org/10.1016/j.foodres.2011.06.033

Wallace, C.A., Sperber, W.H., \& Mortimore, S.E., (2018). Food Safety for the 21st Century: Managing HACCP and Food Safety Through the Global Supply Chain, Second Edition. Wiley Blackwell

Williams, A. (2010). HACCP systems for ensuring the food safety of canned fish products. Fish Canning Handbook, 51-84.

Winter, S., Berente, N., Howison, J. \& Butler, B. (2014). Beyond the organizational 'container': Conceptualizing 21st century sociotechnical work. Information and Organization, 24(4), 250-269 https://doi.org/10.1016/].infoandorg.2014.10.003

Wiśniewska, M. Z. (2015). HACCP-based food defense systems. Journal of Management and Finance, 13, 106-119

World Health Organisation, (WHO) (2009), Global health risks: mortality and burden of disease attributable to selected major risks, Available at:

https://www.who.int/healthinfo/global burden disease/GlobalHealthRisks report full.pdf?ua=1\&ua=1 (accessed 18 October 2018)

World Health Organisation, (WHO) (2015), Food Safety: What you should know, World Health Day: 7 April 2015 , http://www.searo.who.int/entity/world health day/2015/whd-what-you-should-know/en/\#intro (accessed 18 October 2018)

Yeasmin, S. \& Rahman, K.F. (2012), Triangulation research method as the tool of social science research, BUP Journal, 1(1), 154-163.

Yoe, C. \& Schwartz J.G. (2010), Incorporating Defense into HACCP, "Food Safety Magazine" August/September 2010 Available at: https://www.foodsafetymagazine.com/magazinearchive1/augustseptember-2010/incorporating-defense-into-haccp/ (accessed on 10 October 2018)

Zhang, M., Qiao, H., Wang, X., Pu, M., Yu, Z. \& Zheng, F. (2015). The third-party regulation on food safety in China: A review. Journal of Integrative Agriculture, 14(11), 2176-2188. https://doi.org/10.1016/S20953119(15)61114-5

Zhu, X., Huang, I.Y \& Manning, L. (2019). The role of media reporting in food safety governance in China: a dairy case study, Food Control 96, 165-179. https://doi.org/10.1016/j.foodcont.2018.08.027 
1664 
Table 1: Multiple definitions and descriptions associated with public and private standards 2006; Theuvsen \& Spiller 2007; Schulze, Albersmeier, Gawron, Spiller, \& Theuvsen, 2008;

\begin{tabular}{|c|c|}
\hline Term & Description / definition \\
\hline Certification & The (voluntary) assessment and approval by an accredited party on an accredited standard \\
\hline $\begin{array}{l}\text { Legally-mandated } \\
\text { private standards }\end{array}$ & $\begin{array}{l}\text { Standards developed by the private sector, which are then made mandatory by public } \\
\text { bodies. }\end{array}$ \\
\hline $\begin{array}{l}\text { Private standard/ } \\
\text { Optional laws }\end{array}$ & $\begin{array}{l}\text { Public (voluntary) standards are created by public bodies and the adoption is voluntary, } \\
\text { these standard are also called 'optional laws'. Standards developed and adopted by private } \\
\text { bodies. }\end{array}$ \\
\hline $\begin{array}{l}\text { Process-oriented } \\
\text { standards }\end{array}$ & $\begin{array}{l}\text { Standards aimed at assuring that processes are designed, validated and verified in } \\
\text { accordance to certain requirements on e.g. food safety, quality, environment-friendly, } \\
\text { welfare etc.). }\end{array}$ \\
\hline $\begin{array}{l}\text { Product-oriented } \\
\text { standards }\end{array}$ & $\begin{array}{l}\text { Set requirements on particular products and or ingredients. Define specifications for } \\
\text { individual products or product groups aimed at harmonizing product quality to facilitate } \\
\text { trade and to avoid consumer fraud. Examples are: gluten free, ISO product standards with } \\
\text { requirements on pesticides, mycotoxins, heavy metals, etc. }\end{array}$ \\
\hline $\begin{array}{l}\text { Public } \\
\text { standard/regulations }\end{array}$ & Standards enacted in laws, also called regulations. \\
\hline Quality standards & $\begin{array}{l}\text { Quality standards refer to specific schemes for assurance of high quality line products } \\
\text { usually associated with culinary products with particular gustative attributes. }\end{array}$ \\
\hline Standard & Measures by which products, processes and producers are judged \\
\hline Standard owner & $\begin{array}{l}\text { Standard owners can be (local) governments (state-run systems e.g., organic farming in } \\
\text { Denmark); international standardization organisations (e.g., ISO } 9001 \text { and } 22000 \text { ), specific } \\
\text { stakeholders (e.g., Fairtrade); producer schemes (e.g., farmers' associations); private } \\
\text { inspection bodies (e.g. Lloyds); retailer driven schemes (e.g., BRC Global Standard and } \\
\text { IFS) }\end{array}$ \\
\hline $\begin{array}{l}\text { System-oriented } \\
\text { standards }\end{array}$ & Standards setting requirements on (e.g. management) systems (like IFS, ISO9001:2015) \\
\hline
\end{tabular}




\begin{tabular}{|c|c|c|c|c|c|}
\hline \multirow[t]{2}{*}{ Period } & \multirow{2}{*}{$\begin{array}{l}\text { Introducti } \\
\text { on } \\
\text { standard }\end{array}$} & \multicolumn{4}{|c|}{ Time periods wherein major modifications of standards were launched } \\
\hline & & $2000-2005$ & $2006-2010$ & $2011-2015$ & $>2015$ \\
\hline $\begin{array}{l}1985- \\
1994\end{array}$ & $\begin{array}{l}1987- \\
\text { ISO9000 } \\
\text { Series }\end{array}$ & $\begin{array}{l}\text { 2000-ISO9001 } \\
\text {-structural change towards } \\
\text { process model; } \\
\text { - based on management } \\
\text { principles } \\
\text {-customer focus, consistency } \\
\text { \& traceability; } \\
\text { - focus on leadership; } \\
\text { - people involvement; } \\
\text { - systems approach; } \\
\text { - continual improvement; } \\
\text { - factual decision-making; } \\
\text {-mutual beneficial supplier } \\
\text { relations }\end{array}$ & $\begin{array}{l}\text { 2008-ISO9001 } \\
\text { clarification of } \\
\text { requirements and } \\
\text { consistency with } \\
\text { ISO14.000 }\end{array}$ & $\begin{array}{l}\text { 2015-ISO9001 } \\
\text {-structural change to high level structure } \\
\text { plan-do-check-act; } \\
\text {-new clause structure based on } \\
\text { management principles } \\
\text { - context (e.g. know all stakeholders, } \\
\text { process risks); } \\
\text {-leadership (e.g. alignment quality policy } \\
\text { with strategic decisions on risks); } \\
\text {-focus on risks and opportunities; support } \\
\text { (meet e.g. customer demands); } \\
\text {-operation (e.g. contingency planning, } \\
\text { control outsourced activities); } \\
\text { - performance evaluation; } \\
\text {-structured approach for continual } \\
\text { improvement }\end{array}$ & \\
\hline $\begin{array}{l}1995- \\
2000\end{array}$ & $\begin{array}{l}1995- \\
\text { SQF1000/ } \\
\text { SQF2000 }\end{array}$ & & & $\begin{array}{l}2010-2013 \\
\text {-new safety fundamentals for animal } \\
\text { production, animal conversion, feed, } \\
\text { storage \& distribution } \\
2014-S Q F \\
\text {-redesigned for all sectors (replaced } \\
\text { SQF2000 and SQF1000; } \\
\text {-new sections added; } \\
\text {-scored surveillance audits; } \\
\text {-new guidance documents }\end{array}$ & $\begin{array}{l}\text { 2016-SQF(vs8) } \\
\text {-tighter practitioners requirements; } \\
\text {-unannounced audits; } \\
\text {-recall tracking; } \\
\text {-fraud GFSI tool; } \\
\text {-revision technical elements }\end{array}$ \\
\hline & $\begin{array}{l}1997- \\
\text { EUREP } \\
\text { GAP }\end{array}$ & & $\begin{array}{l}\text { 2007- } \\
\text { GLOBALG.A.P } \\
\text { renaming } \\
\text { 2007-local GAPS } \\
\text { e.g. Asian GAPS, } \\
\text { China GAP, } \\
\text { JapanGap, } \\
\text { VietGAp, MyGap_ } \\
\text { national GAPS }\end{array}$ & $\begin{array}{l}\text {-2013 GLOBALG.A.P + Add-on product. } \\
\text { - introduction of GLOBALG.A.P Risk } \\
\text { Assessment on Social Practice (GRASP), } \\
\text { which includes a voluntary module for risk } \\
\text { assessment on social practice, } \\
\text { addressing specific aspects of workers' } \\
\text { health, safety and welfare. } \\
\text { 2014- GLOBALG.A.P } \\
\text { - introduction new Harmonized Produce } \\
\text { Safety Standard (HPSS) to serve need of } \\
\text { US fruit \& vegetable producers to align } \\
\text { with FDA }\end{array}$ & $\begin{array}{l}\text { 2018 GLOBALG.A.P } \\
\text {-addition Produce Handling Assurance } \\
\text { Standard (PHAS) covering pre- process } \\
\text { production after harvesting } \\
\text { 2016- GLOBALG.A.P } \\
\text {-modular approach with modules for a } \\
\text { farm types; part I quality management } \\
\text { rules, part II certification and accreditati } \\
\text { rules } \\
\text { 2015 GLOBALG.A.P } \\
\text {-Revision of GRASP }\end{array}$ \\
\hline
\end{tabular}




\begin{tabular}{|c|c|c|c|c|c|}
\hline & $\begin{array}{l}1997- \\
\text { BRC }\end{array}$ & $\begin{array}{l}\text { 2005-BRC } \\
\text {-introduction additional BRC } \\
\text { standards (packaging, } \\
\text { consumer products, storage } \\
\text { \& distribution) }\end{array}$ & $\begin{array}{l}2007-B R C \\
\text { - emphasize } \\
\text { senior } \\
\text { management } \\
\text { commitment; } \\
\text {-new sections } \\
\text { (allergens); } \\
\text { - rigorous grading } \\
\text { system for } \\
\text { auditing; } \\
\text { - auditor } \\
\text { competence } \\
\text { requirements }\end{array}$ & $\begin{array}{l}\text { 2011-BRC } \\
\text {-emphasize on GMP; } \\
\text { - reduction multiple customer audits; } \\
\text { - more detailed prescriptive } \\
\text { requirements; } \\
\text { - unannounced audit scheme; } \\
\text { - new auditor training } \\
\text { 2015 BRC } \\
\text {-audit process consistency; } \\
\text {-requirement on system to reduce fraud } \\
\text { exposure; } \\
\text { - supply chain transparency \& traceability; } \\
\text { - adoption for small sites; } \\
\text { - new sections and clauses added; } \\
\text { - new voluntary modules: } \\
\text { - trade goods, } \\
\text { - management animal feed; } \\
\text { - Global GAP chain of custody; } \\
\text { - meat supply chain assurance, } \\
\text { - gluten free products; } \\
\text { - food safety culture, } \\
\text { - BRC FSMA }\end{array}$ & $\begin{array}{l}2018 \text { BRC (version 8) } \\
\text { Some major changes } \\
\text { - encouraging development food safety } \\
\text { culture } \\
\text {-expanding requirements for } \\
\text { environmental monitoring } \\
\text { - section on high risk, high care and } \\
\text { ambient high care requirements } \\
\text { - Requirements on traded goods } \\
\text { - whistleblower system must be integrate } \\
\text { to ensure all food safety concerns can b } \\
\text { reported and handled confidentially } \\
\text {-addition cyber security clause on how } t \\
\text { handle cyber attacks or failures in intern } \\
\text { security }\end{array}$ \\
\hline \multirow[t]{2}{*}{$\begin{array}{l}2001- \\
2005\end{array}$} & $\begin{array}{l}\text { 2003-IFS } \\
\text { food }\end{array}$ & $\begin{array}{l}\text { Introduction other IFS } \\
\text { standards logistics, global } \\
\text { markets, food store, etc. }\end{array}$ & $\begin{array}{l}2008-\text { IFS food } \\
\text {-focus senior } \\
\text { management }\end{array}$ & $\begin{array}{l}\text { 2012-IFS food } \\
\text { - more weight to quality criteria; } \\
\text { - packaging risks; } \\
\text { - food defense requirements; } \\
\text { - integrity program to monitor auditors; } \\
\text {-additional requirements on validation, } \\
\text { verification and documentation } \\
\end{array}$ & \\
\hline & \begin{tabular}{|l|}
$2005-$ \\
ISO22000 \\
FSMS
\end{tabular} & & $\begin{array}{l}\text { 2007-ISO22005 } \\
\text { - traceability in } \\
\text { feed and food chain } \\
\text { 2009-ISO22002 } \\
\text { - specific } \\
\text { prerequisites food } \\
\text { manufacturing }\end{array}$ & $\begin{array}{l}\text { 2011-ISO22001 } \\
\text {-prerequisites farming } \\
\text { 2013-ISO22002 } \\
\text {-prerequisites catering and packaging } \\
\text {-ISO22003 guidelines for audit and } \\
\text { certification bodies }\end{array}$ & $\begin{array}{l}\text { 2018-ISO222000 } \\
\text {-structural revision based on revision } \\
\text { ISO9001:2015; with the high level } \\
\text { structure, plan-do-check-act; } \\
\text {-focus on business context and interest } \\
\text { parties } \\
\text {-Strengthened emphasis on leadership } \\
\text { and management commitment } \\
\text {-Risk management (impact assessment } \\
\text { positive and negative) } \\
\text {-Strengthened focus on objectives as } \\
\text { drivers of improvement } \\
\text { - Extended requirements on } \\
\text { communication }\end{array}$ \\
\hline
\end{tabular}




\begin{tabular}{|l|l|l|l|l|}
\hline & & & & \\
\hline $2006-$ & $\begin{array}{l}2009- \\
\text { FFSC220 } \\
00\end{array}$ & & & $\begin{array}{l}\text { 2012-FFSC 22000 } \\
\text {-adds new scope for food packaging } \\
\text { manufacturers } \\
\text { 2014-FFSC 22000 } \\
\text {-adds new scope for manufacturing } \\
\text { animal feed } \\
\mathbf{2 0 1 5} \\
\text {-adds voluntary model based on ISO9001 }\end{array}$ \\
\hline
\end{tabular}

- Less strict requirements on food safety manual

-management facilitate understanding

food safety policies by employees

-establishing FSMS objectives

- control externally provided processes, products or services

\section{6-FFSC22000}

-new requirements;

-unannounced audits:

- critical nonconformities;

-standardized audit report;

- prevention intentional product

contamination;

-requirements for transport \& storage,

BRC (2015, 2018), https://brc.org.uk/about-brc; FSSC 22000, http://www.fssc22000.com/documents/home; GLOBALG.A.P https://www.globalgap.org; ISO 9000 (2015), https://www.iso.org/; ISO (2005, 2018); IFS (2018), https://www.ifs-

1678 certification.com/index.php/en/standards; SQF https://www.sqfi.com/standards). 


\begin{tabular}{|c|c|}
\hline Characteristics & Examples \\
\hline \multicolumn{2}{|r|}{ External characteristics } \\
\hline Legal context & Internal framing driven by enforcement philosophy and practices. Sufficiency of food safety authorities \\
\hline National culture & National values, beliefs, norms related to food safety \\
\hline Socio-political context & Corruption index, stability, economic situation \\
\hline Supply chain context & $\begin{array}{l}\text { Transparency in the supply chain network, power relations, domestic versus export markets, competitiveness, and interconnectedness. } \\
\text { Severity and flexibility of stakeholder requirements. Information exchange and degree of asymmetry. Sophistication of logistic infrastructure. } \\
\text { Degree of globalization of the supply chain and degree of interaction of national cultures and their approach to food safety. }\end{array}$ \\
\hline \multicolumn{2}{|r|}{ Internal characteristics } \\
\hline $\begin{array}{l}\text { Business and } \\
\text { Administrative }\end{array}$ & $\begin{array}{l}\text { Communication - Vision, mission, policy, strategy on FS-culture and FSMS development - skills, different languages/culture, message } \\
\text { consistency, along all channels, crucial role middle management. Leadership - moral engagement, enlightenment, reinforcement, employee } \\
\text { involvement, truly involvement leaders, empower people. Training and learning - Both operator/management training, create FS-culture learning } \\
\text { environment, respectful feedback, trust, connect information to action, learning from peers, tailored to users/company specific, knowing controls } \\
\text { and consequences of failures, share experiences with other businesses, use various techniques (story telling, movies). Recruitment and } \\
\text { employee development - effective interviewing and appointment, setting basic requirements, personal development, incentives/rewards, moral, } \\
\text { feedback. Use of artefacts and symbols. }\end{array}$ \\
\hline $\begin{array}{l}\text { Group (Group, } \\
\text { department or team) }\end{array}$ & $\begin{array}{l}\text { Objective characteristics such as multidisciplinary, cross functional collaboration, type and size e.g. HACCP team, shift operators, group roles. } \\
\text { Subjective or social interactions e.g. communication styles, group behaviour, conflicts, power relations, individual versus group decision } \\
\text { behaviour and more individuals acting at the group level. Group and social norms e.g. normative standards, attitudes, perceived degree of } \\
\text { behavioural control. Recognition and acceptance of group member differences in communication styles, in understanding, in culture. } \\
\text { Engagement - common ownership, all group members being ambassadors of food safety in their work area }\end{array}$ \\
\hline Individual & $\begin{array}{l}\text { Demographics e.g. age, gender, seniority, education. Psychological e.g. attitude, beliefs, values, norms, habits, personality, personal perception } \\
\text { of risks, safety, hazards, etc. Knowledge and understanding of food safety/risks, awareness, experience. Psycho-social wellbeing i.e. stress, } \\
\text { job satisfaction, perceived reward, etc. }\end{array}$ \\
\hline Organizational & $\begin{array}{l}\text { Level of formalization (formal/informal) structured systems i.e. degree of adoption of manuals, procedures, work instructions. Level of } \\
\text { information system: record keeping, data collection, archiving and retrieval. Organizational arrangements size \& complexity, definition and } \\
\text { division of tasks, responsibility, rules, authority. Structure i.e. central focus or decentralized, hierarchy, and the interaction of strategic, tactical } \\
\text { and operational decision-making. Stability of workforce, competence level of workforce, staff turnover. Resource use - primarily financial, } \\
\text { physical, human capital. Workforce composition and variability }\end{array}$ \\
\hline Product & $\begin{array}{l}\text { Intrinsic properties of raw materials, in-process material and finished products. Food safety risk associated with the initial materials and } \\
\text { product (risk associated with allergenic, biological, chemical and physical hazards) }\end{array}$ \\
\hline Production & $\begin{array}{l}\text { Conditions during production including operational design, technical infrastructure. Food safety risk associated with the production site and } \\
\text { the physical processes employed. Vulnerabilities and susceptibility to loss of control or contamination. }\end{array}$ \\
\hline Technical & $\begin{array}{l}\text { Technical resources e.g. facilities, equipment, personnel. Control activities including preventative measures, monitoring and verification } \\
\text { systems in FSMS. Facility design e.g. hygienic zoning, lay-out, routing. Process design e.g. hygienic design, process capability. Equipment }\end{array}$ \\
\hline
\end{tabular}


Table 4. Internal and external triggers that influence FSMS and FCS (Adapted from: Leat \& Revoredo-Giha, 2003; Kleboth et al. 2016;

1683 Manning \& Soon, 2016a)

\begin{tabular}{|l|l|}
\hline \multicolumn{1}{|c|}{ Internal triggers } & \multicolumn{1}{c|}{ External triggers } \\
\hline Wake up call -internal incident/company recall & Wake up call -incident in sector \\
New CEO & Negative media attention on an issue e.g. foof safety, food fraud \\
Internal policy changes & Regulatory and legislative changes \\
New products/product areas & Industry or trade association drive new standards or criteria for compliance \\
New brands/existing brands extension & Lobby groups \\
New technologies & Changing consumer demands \\
Audit results & Market and pricing strategies; low operating margins \\
Changing customer requirements & Natural disasters, technological accidents, infectious disease (Leat \&) \\
\hline
\end{tabular}


Table 5. Hierarchy in decision making within a food organization (adapted from Luning \& Marcelis, 2007, 2009; Nyarugwe et al. 2016)

\begin{tabular}{|c|c|c|}
\hline $\begin{array}{c}\text { Strategic level } \\
\text { CEO and executive board }\end{array}$ & $\begin{array}{c}\text { Tactical level } \\
\text { Middle management }\end{array}$ & $\begin{array}{c}\text { Operational level } \\
\text { Food handlers, operators }\end{array}$ \\
\hline 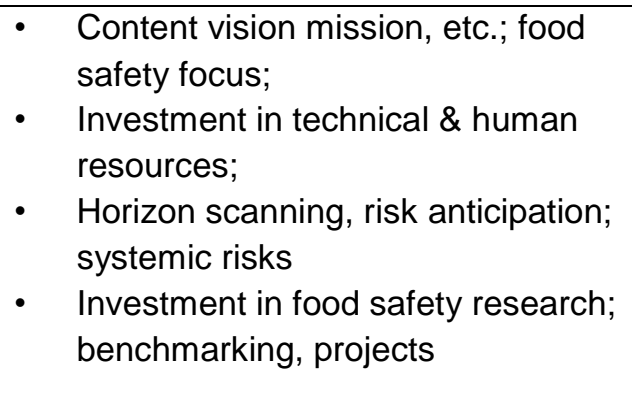 & $\begin{array}{ll} & \text { Design, implementation \& } \\
\text { maintenance FSMS; } \\
\text { - Dealing with audit \& review findings; } \\
\text { Data analysis for continuous } \\
\text { improvement; } \\
\text { - Dealing with daily safety \& hygiene } \\
\text { issues; } \\
\text { - Training, instruction, feedback } \\
\text { operators }\end{array}$ & $\begin{array}{ll}\text { - } & \text { Compliance to safety \& hygiene } \\
\text { procedures } \\
\text { - } & \text { Feedback to peers \& supervisors } \\
\text { - } & \text { Communication observations (near } \\
\text { misses) etc. }\end{array}$ \\
\hline
\end{tabular}


1691

1692 


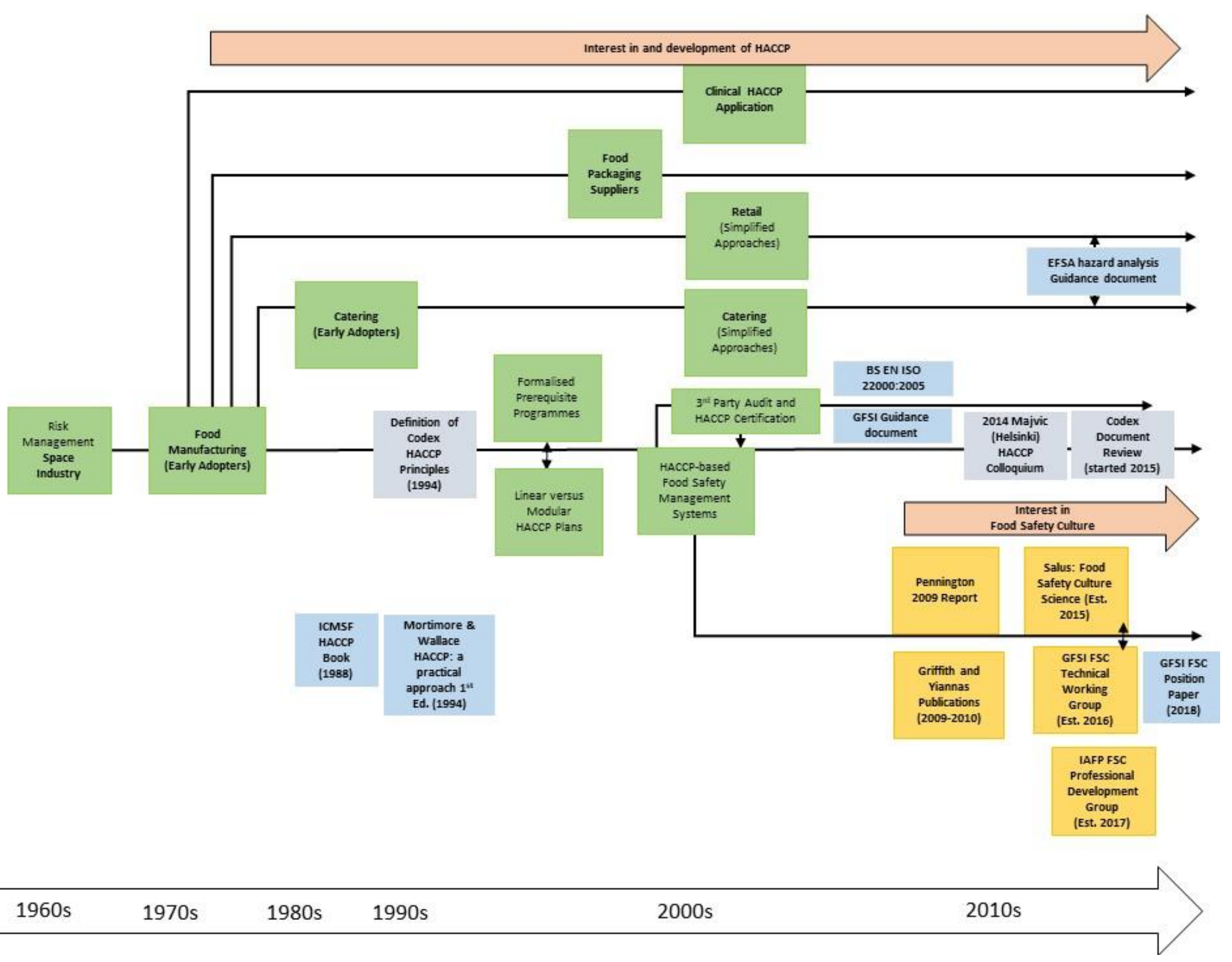

1693

Figure 1: Timeline for the adoption of HACCP based approaches to managing food safety (Wallace, 2014) 


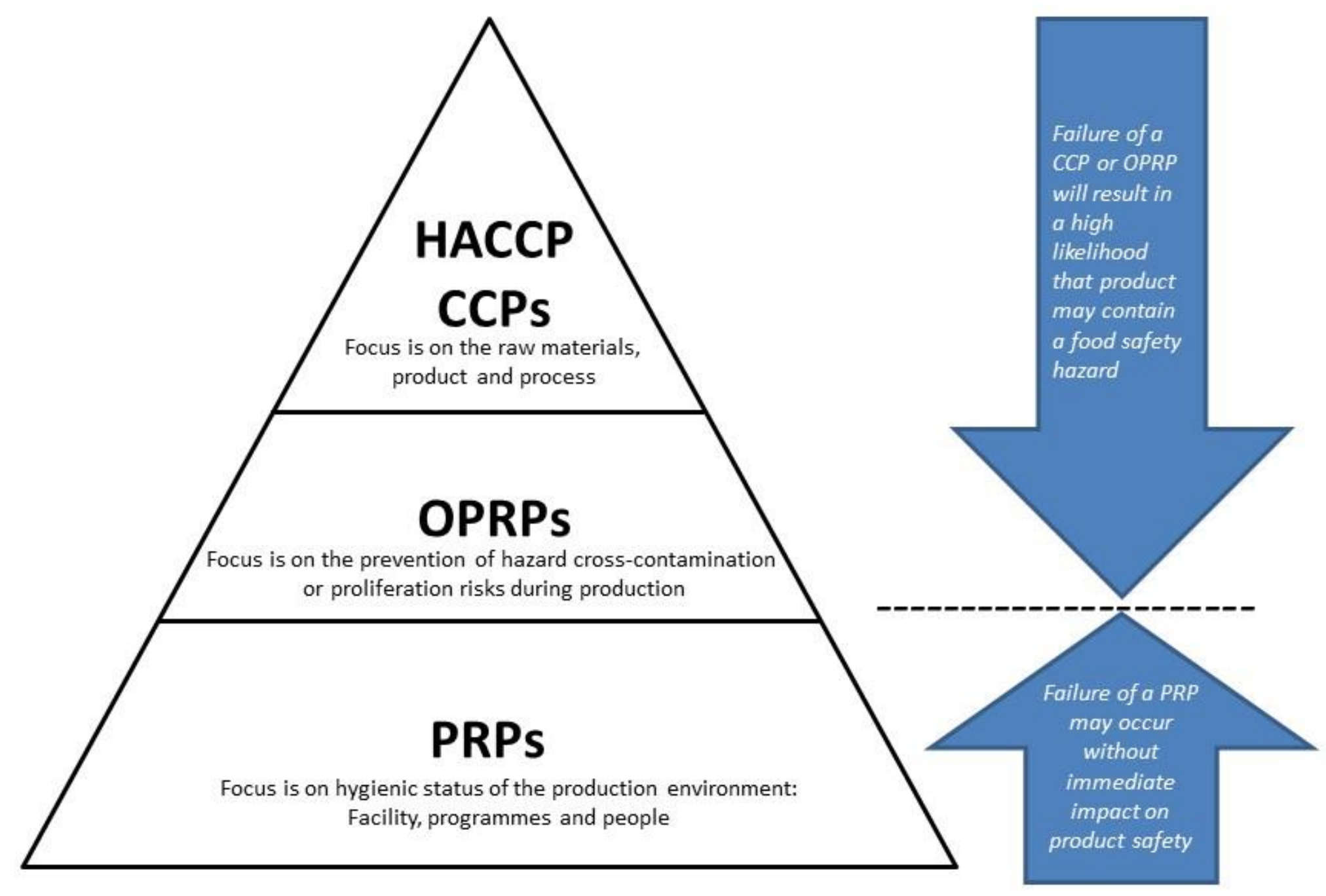

1696 Figure 2. The relationship between HACCP, OPRPs and PRPs (adapted from Mortimore \& Wallace, 2013) 


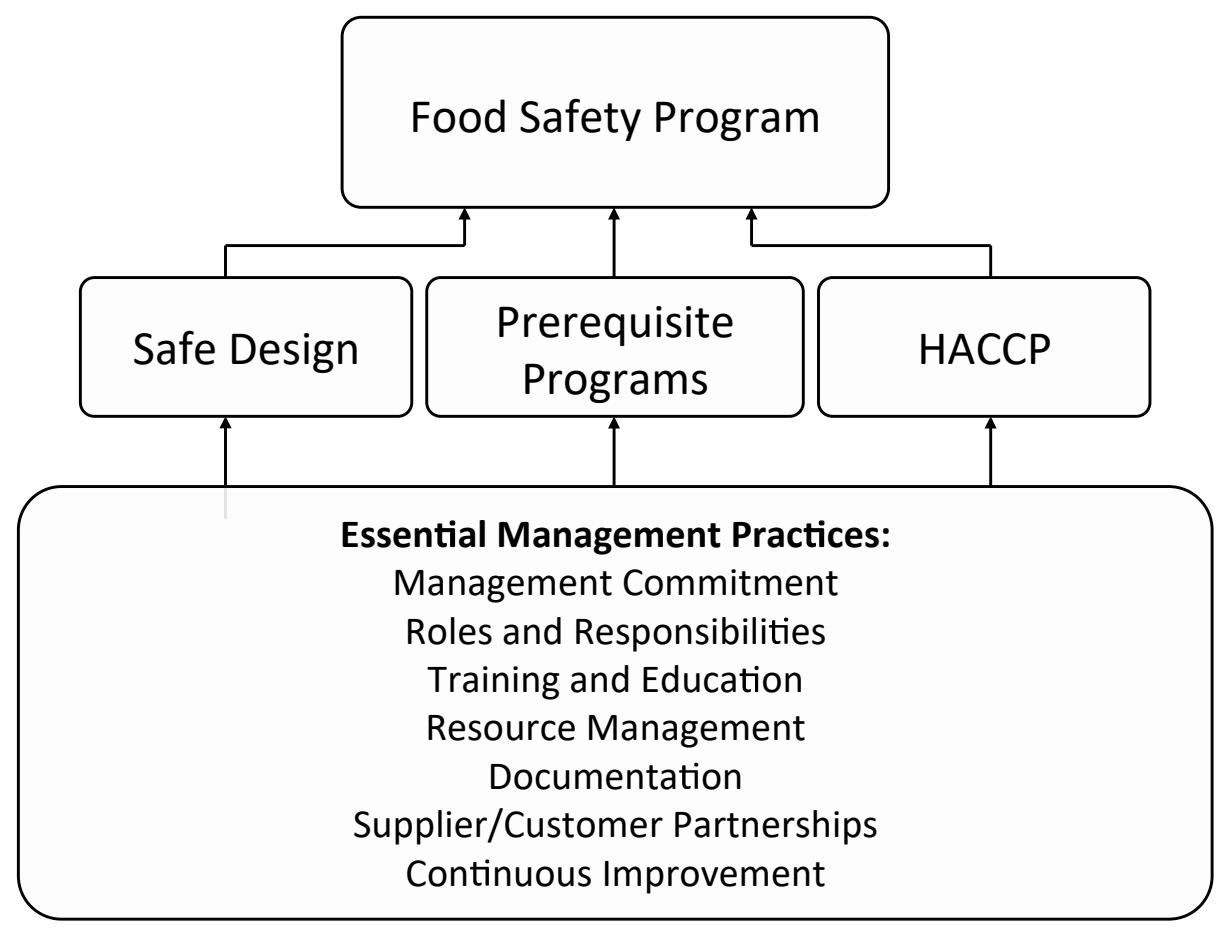

1698

1699 Figure 3. HACCP as a building block of a food safety management program (Source: Wallace, Sperber \& Mortimore, 2011) 
Drivers/motives for adoption standard

- Access global markets

- Requirement imposed by retailers

- Peer pressure

- Reduce transaction costs

- Reduce supply risks

- Facilitate B2B relations

- Protect brand reputation

- Build consumer loyalty

- Improve productivity and efficiency

Differentiate in competitive markets

Barriers for adoption standards

- Restricted access to information

- Lack of knowledge and experience

- High investments needed

- Jungle of numerous different standards required by customer

Drivers for development standards

Shortcoming traditional inspections

- Globalisation food supply chains

- New procurement strategies

- Costs individual supplier

assessment schemes

- Legal liability framework

Strengthening consumer confidence

Multiple food affairs

- Limited capacity public bodies

- Weak food legislation frameworks in emerging/developing countries

- Fats changing in quality attributes and innovations

- Selection standards

- Validation \& implementation

- Verification, review \& internal audits

- Increase acceptance of private standards

- Modifications

\section{Operational food production systems}

0

\section{quality}

integrity

\section{Impact of standards}

- Improvement supplier relationships

- Facilitated HACCP interpretation and application

- More efficient auditing

- More effective monitoring procedure

- More efficient management

- Higher conformity to objectives
- Some standards perceived as rigid, paternalistic approach

- General loss of flexibility

- Reduction independent reflective thinking due to detailed procedures/regulations

- Still retailer audits although certified

- Negative cost/benefit ratio

- Bureaucratic/lots of paperwork

- Lowering supplier preference for strictly regulated European markets 
Figure 4: Drivers and barriers for standard development and adoption, and their impact; model based on Luning \& Marcelis (2009) and drivers, barriers and impact derived from academic reviews and empirical studies (Latouche \& Chevassus-Lozza, 2015; Spadoni,

Lambardi \& Canavari, 2013; Herzfeld, Drescher \& Grebitus, 2011; Henson \& Humphrey, 2010; Schulze, Albersmeier, Gawron, Spiller \& Theuvsen, 2008; Theuvsen \& Spiller, 2007; Fulponi, 2006; Henson \& Reardon, 2005)
1707

1708

1709

1710

1711

1712 